\title{
Oxygen reduction characteristics of several valve metal oxide electrodes in $\mathrm{HClO}_{4}$ solution
}

Yoshio Takasu*, Masatoshi Suzuki, Hongsheng Yang, Tatsuya Ohashi, and Wataru Sugimoto

Department of Materials and Chemical Engineering, Faculty of Textile Science and Technology, Shinshu University, 3-15-1 Tokida, Ueda 386-8567, Japan

\begin{abstract}
In the search for active cathode catalysts for polymer electrolyte fuel cells (PEFCs) using inexpensive materials, several valve metal oxide electrodes, $\mathrm{TiO}_{x}$, $\mathrm{ZrO}_{x}, \mathrm{TaO}_{x}$, with corresponding binary oxide electrodes were selected for the evaluation of catalytic activity for oxygen reduction reaction (ORR) by means of cyclic voltammetry in $0.1 \mathrm{M} \mathrm{HClO}_{4}$ at $60^{\circ} \mathrm{C}$. These oxide electrodes were prepared mainly by the dip-coating method on a titanium plate substrate at a temperature between $400^{\circ} \mathrm{C}$ and $500^{\circ} \mathrm{C}$ and were characterized by scanning electron microscopy (SEM), X-ray diffractometry (XRD), and X-ray photoelectron spectroscopy (XPS). Among the oxide-coated electrodes investigated, $\mathrm{Ti}_{0.7} \mathrm{Zr}_{0.3} \mathrm{O}_{x} / \mathrm{Ti}$ provided the highest ORR specific activity, with an onset potential, $E_{\mathrm{ORR}}$, of $0.86 \mathrm{~V}$ vs. RHE during the cathodic potential sweep. Fine $\mathrm{TaO}_{x}$ particles prepared as an extension of the dip-coating method, showed very high catalytic activity determined by means of hydrodynamic voltammetry in $0.1 \mathrm{M} \mathrm{HClO}_{4}$ at $30^{\circ} \mathrm{C}$ with an $E_{\mathrm{ORR}}$ of $0.90 \mathrm{~V}$ vs. RHE.
\end{abstract}


Keywords: Titanium, Zirconium, Tantalum, Oxygen reduction reaction, Electrocatalyst

\author{
* Corresponding author \\ E-mail address: ytakasu@shinshu-u.ac.jp (Y. Takasu)
}

\title{
1. Introduction
}

Although fuel cells have attracted public attention in terms of both environment factors and convenience, the technology is not yet widely used mainly due to issues regarding cost and durability. The typical cathode catalysts presently used for polymer electrolyte fuel cells (PEFCs) are expensive Pt-based catalysts with high oxygen reduction activity [1-3]; however, practical use requires higher durability, and the dissolution and coagulation of the platinum must be minimized [4,5]. Various approaches have been taken to overcome these problems, with a particular focus on searching for suitable non-platinum elements, including oxides [6-9], carbides [10], nitrides, silicides, metal complexes [11,12], and other compounds [13-15]. Recently, some interesting studies were reported on the development of Pt-free oxide cathodes, such as Ta-O-N, Ta-C-N-O, and Nb-C-N-O [16-21]. In previous investigations [8,9], we reported the ORR activity of dip-coated $\mathrm{IrO}_{2} / \mathrm{Ti}$ catalyst electrodes. An increase in catalytic activity was attained by using lanthanum in the preparation of oxide-coated catalyst electrodes. We have tested valve metal oxides as candidate cathode catalysts for PEFCs because they are stable in acid. Although the 
cathodic properties of oxynitrides, oxycarbonitrides and oxides of several valve metals have already been reported, the preparation involves high temperatures or sputtering. All oxide catalysts in this investigation were prepared at a temperature lower than $500^{\circ} \mathrm{C}$; therefore, the crystallite size was small and probably contained a large number of oxide-ion lattice defects.

This study presents the basic physical properties and the ORR results for titanium oxide, zirconium oxide, tantalum oxide catalysts, and some of the corresponding binary oxides, using a Ti plate substrate prepared mainly by the dip-coating method at a temperature between $400^{\circ} \mathrm{C}$ and $500^{\circ} \mathrm{C}$. The results may provide approaches for designing less expensive oxide cathode catalysts for ORR.

\section{Experimental}

\subsection{Preparation of oxide-coated electrodes by the dip-coating method}

The oxide-coating film of each valve metal was prepared on a Ti plate $(10 \times 10 \times 1 \mathrm{~mm})$ substrate by the conventional dip-coating method [22-25] using a $0.5 \mathrm{M}$ butanolic solution of metal salt: titanium tetrabutoxide, zirconium tetrabutoxide or tantalum pentachloride. The titanium substrate was etched with $10 \%$ oxalic acid at $80^{\circ} \mathrm{C}$ for $1 \mathrm{~h}$ and then rinsed with deionized water before the dipping procedure. Calcination of the dip-coated salts was conducted in air at various temperatures between $400^{\circ} \mathrm{C}$ and $500^{\circ} \mathrm{C}$. The dip-drying/calcination (alternating $10 \mathrm{~min}$ each) procedure was typically repeated 5 times. In addition, $\mathrm{TaO}_{x}$ powder was prepared as follows. First, $\mathrm{TaO}_{x}$ oxide was formed on a porous titanium disk (Tiporous ${ }^{\circledR}$ purchased from Osaka Titanium Technologies Co., Ltd.) by the dip-coating method with the same dip-coating solution used to prepare the $\mathrm{TaO}_{x} / \mathrm{Ti}$ electrode. The calcination 
in air was carried out at $320^{\circ} \mathrm{C}$ for $10 \mathrm{~min}$. The $\mathrm{TaO}_{x} /$ Tiporous ${ }^{\circledR}$ was then ultra-sonicated in water to remove the $\mathrm{TaO}_{x}$ particles from the Tiporous ${ }^{\circledR}$ disk. The $\mathrm{TaO}_{x}$ particles were separated from the water with a centrifugal separator followed by drying at room temperature and calcination in air at $450^{\circ} \mathrm{C}$ for $30 \mathrm{~min}$.

2.2 Characterization of the physical properties of the various oxide-coated electrodes and oxide powder

The structures of the oxide-coated electrodes and $\mathrm{TaO}_{x}$ powder were characterized using two different scanning electron microscopes (SEM; Hitachi S-3000N; and HR-SEM, Hitachi S-5000) and X-ray diffraction (XRD, Rigaku RINT-2550 with monochromated $\mathrm{CuK}_{\alpha}$ radiation at $40 \mathrm{kV}$ and $40 \mathrm{~mA}$ ). The XRD profiles in the $2 \theta$ range of $15 \sim 90^{\circ}$ were scanned at a speed of $2^{\circ} \mathrm{min}^{-1}$. The chemical species of the surfaces were characterized by X-ray Photoelectron Spectroscopy (XPS, Kratos Analytical, AXIS ULTRA) with $\mathrm{MgK}_{\alpha}$ radiation at $15 \mathrm{kV}$ and $15 \mathrm{~mA}$. The binding energy of the photoelectrons was calibrated with that of C1s (284.6 $\mathrm{eV})$. The BET surface area of the $\mathrm{TaO}_{x}$ powder was determined with BELSORP-28 (BEL Japan Inc.) using nitrogen as an adsorbent.

\subsection{Electrochemical measurements}

The ORR activity of the oxide electrodes was evaluated by cyclic voltammetry $(\mathrm{CV})$ in $0.1 \mathrm{M} \mathrm{HClO}_{4}$ using a beaker-type electrolytic cell in a stationary state at $60^{\circ} \mathrm{C}$. A hydrogen electrode was used as the reference electrode, and a bundle of carbon fibers, rather than Pt, was used as the counter 
electrode to avoid $\mathrm{Pt}$ deposition onto the test electrode through dissolution. A Luggin capillary was set facing the working electrode at a distance of $2 \mathrm{~mm}$. All electrode potentials refer to the $\operatorname{RHE}(t)$ scale, corrected for the temperature effect. For the ORR experiment, oxygen gas was bubbled into the $0.1 \mathrm{M} \mathrm{HClO}_{4}$ solution at $60^{\circ} \mathrm{C}$. In addition to the above method, the rotating disk electrode (RDE) was applied to the more precise evaluation of the ORR behavior of $\mathrm{TaO}_{x}$ powder. The working electrodes were prepared using the thin-film electrode method [26,27]. Briefly, a mixed powder of $\mathrm{TaO}_{x}$ and carbon black (CB; Vulcan $\mathrm{XC}-72 \mathrm{R}$ ) was loaded on the glassy carbon surface of the RDE electrode and then was fixed with Nafion ${ }^{\circledR}$ ionomer. The loading amount of the $\mathrm{TaO}_{x}$ and the loading ratio of the $\mathrm{TaO}_{x}$ to $\mathrm{CB}$ in weight were $1.0 \mathrm{mg} \mathrm{cm}^{-2}$ and 95:5, respectively.

\section{Results and Discussion}

3.1 Basic physical properties of $\mathrm{TiO}_{x} / \mathrm{Ti}, \quad \mathrm{ZrO}_{x} / \mathrm{Ti}, \mathrm{Ta} \mathrm{O}_{x} / \mathrm{Ti}$, and binary oxide-coated electrodes

The surface morphology of the $\mathrm{TiO}_{x} / \mathrm{Ti}, \mathrm{ZrO}_{x} / \mathrm{Ti}$ and $\mathrm{TaO}_{x} / \mathrm{Ti}$ electrodes after the electrochemical measurement for the ORR in $0.1 \mathrm{M} \mathrm{HClO}_{4}$ was observed by scanning electron microscopy. Typical micrographs at different magnifications are shown in Figs. 1 and 2. The $\mathrm{TiO}_{x} / \mathrm{Ti}$ electrode had only a few isolated mud cracks on the surface and was composed of very fine particles that were connected to each other and formed meso-pores less than a few nanometers in width, as seen on (a)-2 in Fig. 2. On the other hand, the $\mathrm{ZrO}_{x} / \mathrm{Ti}$ electrode had no mud cracks and was composed of fine particles with $0.1 \sim 0.3 \mu \mathrm{m}$ in diameter that were connected to each other and formed macro-pores. On the $\mathrm{TaO}_{x} / \mathrm{Ti}$ electrode, 
many isolated cracks were observed; however, no oxide particles were observed even on the micrograph at the highest magnification (Fig. 2, (c)-2) used in this study. No appreciable differences in the surface morphology were observed for these oxide-coated electrodes before and after the electrochemical measurement described in Section 2.3. Figure 3 shows a comparison of the surface morphology of the pristine $\mathrm{ZrO}_{x} / \mathrm{Ti}$ electrode and that of the electrode exposed to the electrochemical measurement described in Section 2.3.

The morphology of the Ti-Zr-O/Ti binary electrodes was affected by the characteristics of the $\mathrm{TiO}_{x} / \mathrm{Ti}$ and $\mathrm{ZrO}_{x} / \mathrm{Ti}$ electrodes. As shown in Fig. 4, the $\mathrm{Ti}_{0.7} \mathrm{Zr}_{0.3} \mathrm{O}_{x} / \mathrm{Ti}$ electrode had isolated cracks on the surface; however, the $\mathrm{Ti}_{0.5} \mathrm{Zr}_{0.5} \mathrm{O}_{x} / \mathrm{Ti}$ and $\mathrm{Ti}_{0.3} \mathrm{Zr}_{0.7} \mathrm{O}_{x} / \mathrm{Ti}$ electrodes had no cracks and, like the $\mathrm{ZrO}_{x} / \mathrm{Ti}$ electrode, were composed of small, connected oxide particles forming a macro-pore structure. For the Ti-Ta-O/Ti binary electrodes (Fig. 5), typical connected mud cracks were observed on the $\mathrm{Ti}_{0.5} \mathrm{Ta}_{0.5} \mathrm{O}_{x} / \mathrm{Ti}$ and $\mathrm{Ti}_{0.3} \mathrm{Ta}_{0.7} \mathrm{O}_{x} / \mathrm{Ti}$ electrodes, except that a few isolated cracks were observed on the $\mathrm{Ti}_{0.7} \mathrm{Ta}_{0.3} \mathrm{O}_{x} / \mathrm{Ti}$ electrode.

Figure 6 shows the XRD patterns of the various oxide-coated electrodes prepared by the dip-coating method at $450^{\circ} \mathrm{C}$. Since the oxide-coated layers were thin, many diffraction peaks from metallic titanium were observed. For the $\mathrm{TiO}_{x} / \mathrm{Ti}, \mathrm{ZrO}_{x} / \mathrm{Ti}$ and $\mathrm{TaO}_{x} / \mathrm{Ti}$ electrodes, weak anatase $\mathrm{TiO}_{2}$ peaks, weak $\mathrm{ZrO}_{2}$ peaks and broad peaks from $\mathrm{TaO}_{x}$, respectively, were observed. These broad peaks from $\mathrm{TaO}_{x}$ might be assigned as $\mathrm{TaO}_{2}$, because the main three diffraction peaks from tetragonal $\mathrm{TaO}_{2}$ appear at $2 \theta=26.749,34.939$ and 52.718. The Ti-Zn-O/Ti binary electrodes, (d) (f) in Fig. 6, gave no appreciable diffraction peak except the peaks from the Ti substrate; however, a broad peak around $30^{\circ}$ $(2 \theta)$ increased with an increase in the zirconium content. A similar phenomenon 
was observed for the Ti-Ta-O/Ti binary electrodes, shown in (g) (i) in Fig. 6, where no appreciable diffraction peak except the peaks from the Ti substrate was observed; however, broad peaks around 27,35 and $53^{\circ}(2 \theta)$ increased with an increase in the tantalum content, suggesting the formation of ultra-fine $\mathrm{TaO}_{2}$ particles or something like that.

The Ti2p, Zr3d and Ta4f XPS spectra of the Ti-Zr-O/Ti and Ti-Ta-O/Ti binary electrodes exposed to electrochemical measurement are presented in Figs. 7 and 8 , and the values of the binding energy of these elements are listed in Table 1. Although no evident difference was observed in the binding energy for these single and binary oxide-coated electrodes, all of the values were lower than those of $\mathrm{Ti}^{4+}(458.7 \mathrm{eV}), \mathrm{Zr}^{4+}(182.2 \mathrm{eV})$, and $\mathrm{Ta}^{5+}(26.5 \mathrm{eV})$, respectively. This fact strongly suggests that the oxides prepared by the dip-coating method at $450^{\circ} \mathrm{C}$ were formed at a somewhat lower oxidation state than the $\mathrm{TiO}_{2}, \mathrm{ZrO}_{2}$ and $\mathrm{Ta}_{2} \mathrm{O}_{5}$. As presented in Table 1 , the surface content of titanium on these $\mathrm{Ti}-\mathrm{Zr}-\mathrm{O} / \mathrm{Ti}$ and $\mathrm{Ti}-\mathrm{Ta}-\mathrm{O} / \mathrm{Ti}$ electrodes was considerably decreased by the electrochemical measurement described in Section 2.3.

\subsection{ORR catalytic activity of $\mathrm{TiO}_{x} / \mathrm{Ti}, \mathrm{ZrO} \mathrm{O}_{x} / \mathrm{Ti}$, and $\mathrm{TaO} \mathrm{O}_{x} /$ Ti electrodes}

To determine the appropriate number of dip-coating repetitions for the preparation of these oxide electrodes, three $\mathrm{TiO}_{2} / \mathrm{Ti}$ electrodes were prepared at $450^{\circ} \mathrm{C}$ with 2, 5 and 10 dipping repetitions. Since the electrode prepared with 5 repetitions provided the highest ORR activity per geometric surface area of the electrode, the dip-coating procedure was fixed to 5 repetitions throughout this investigation. The ORR onset potentials, $E_{\mathrm{ORR}}$, during the cathodic potential sweep of the $\mathrm{TiO}_{x} / \mathrm{Ti}$ electrodes prepared at $400^{\circ} \mathrm{C}, 450^{\circ} \mathrm{C}$, and $500^{\circ} \mathrm{C}$ were 0.87 , 0.91 and $0.88 \mathrm{~V}$ vs. RHE, respectively. Based on this result, the preparation 
temperature for the oxide electrodes in this investigation was fixed at $450^{\circ} \mathrm{C}$.

Figure 9 shows cyclic voltammograms of the $\mathrm{TiO}_{x} / \mathrm{Ti}, \mathrm{ZrO}_{x} / \mathrm{Ti}$ and $\mathrm{TaO}_{x} / \mathrm{Ti}$ electrodes, which were prepared at $450^{\circ} \mathrm{C}$ and measured in both deaerated $0.1 \mathrm{M}$ $\mathrm{HClO}_{4}$ (broken lines) and in $\mathrm{O}_{2}$-saturated $0.1 \mathrm{M} \mathrm{HClO}_{4}$ (solid lines) at $60^{\circ} \mathrm{C}$. The additional cathodic current of each voltammogram measured in an $\mathrm{O}_{2}$-saturated solution compared to that in the deaerated electrolytic solution shows the reduction in oxygen. These voltammograms provide the following information: (1) the approximate pseudocapacitance value of each oxide catalyst electrode for the voltammograms in the deaerated solution; (2) the ORR onset potential, $E_{\mathrm{ORR}}$, where the reduction in oxygen becomes apparent during the cathodic potential sweep of the test electrodes; and (3) the current density corresponding to the ORR, that is, the current density in the $\mathrm{O}_{2}$-saturated solution deducted from that in the deaerated solution at any potential measured.

Due to the difficulty in determining the surface area of the oxide catalyst layers of these oxide-coated electrodes by the BET method, for example, the pseudocapacitance of these oxide electrodes was evaluated with the anodic voltammetric charge measured in the deaerated $0.1 \mathrm{M} \mathrm{HClO}_{4}$ between 0.4 and 1.0 V (vs. RHE); half the total charge (anodic charge plus cathodic charge) was divided by $0.6 \mathrm{~V}$. Despite a lack of information on the "effective surface area" that actually contributes to ORR in porous oxide electrodes, the current density divided by the pseudocapacitance is used when discussing the specific activity of oxide electrodes. Since not every inner surface of the porous oxide catalysts contributes to ORR due to the restriction in the transport of oxygen through narrow pores, the comparison of specific activity among the oxide catalyst electrodes using the current density divided by the pseudocapacitance has limitations. The pseudocapacitance of these oxide electrodes is listed in Table 2 
along with the respective specific activities, or the ORR current density at 0.7 vs. RHE divided by the respective pseudocapacitance. Under the described conditions of electrode preparation and electrochemical measurement, the $\mathrm{TiO}_{x} / \mathrm{Ti}$ electrode provided the highest ORR specific activity at $0.7 \mathrm{~V}$ vs. RHE. The considerable difference in the morphology of the oxide layer for these three oxide-coated electrodes, as shown in Figs. 1 and 2, must also affect the ORR activity due to the effect of the mass transport of the reactants. As shown in Fig. 2, the $\mathrm{TaO}_{x} / \mathrm{Ti}$ electrode had a smooth surface. While isolated cracks were observed, the pseudocapacitance was almost same as that of the $\mathrm{ZnO}_{x} / \mathrm{Ti}$ electrode and was about $60 \%$ of that of the $\mathrm{TiO}_{x} / \mathrm{Ti}$ electrode. This result means that (1) the effective surface area towards the ORR should be determined for a reasonable comparison of the surface-specific activity of the oxide-coated catalyst electrodes, and (2) the design of an oxide catalyst with a large surface area which can contribute to the ORR is important from a practical viewpoint. Moreover, the electric resistance of these oxide layers must be very low; therefore, the effective surface must be restricted by the region in which electric contact is guaranteed. The $\mathrm{TiO}_{x} / \mathrm{Ti}$ electrode showed the highest activity among these three electrodes, perhaps because of the semi-conductive property of $\mathrm{TiO}_{x}$ prepared at low temperature. In addition to these factors affecting catalytic activity, residual chloride ions usually contained in the oxide layers prepared by the dip-coating method with chloride precursors must also be considered for the discussion of the catalytic activity of oxide catalysts. A precise investigation of both the effective surface area and the precise surface-specific catalytic activity for the ORR is needed in order to examine the morphology, electric conduction and probable effect of impurities such as residual chloride ions. 
3.3 Enhancing the catalytic activity of $\mathrm{TiO}_{x} / \mathrm{Ti}, \mathrm{ZrO} \mathrm{O}_{x} / \mathrm{Ti}$, and $\mathrm{TaO} \mathrm{O}_{x} / \mathrm{Ti}$ electrodes by the formation of binary oxides

The formation of binary oxides is sometimes useful in order to increase the surface area of the oxide due to the inhibition of oxide particle crystallization. In the case of the formation of binary oxides from elements with different valencies, the occurrence of $\mathrm{O}^{2-}$ vacancies and changes in valencies of the constituting metal elements is expected.

Figures 10 and 11 show cyclic voltammograms of the binary oxide electrodes of $\mathrm{Ti}-\mathrm{Zr}-\mathrm{O} / \mathrm{Ti}$ and $\mathrm{Ti}-\mathrm{Ta}-\mathrm{O} / \mathrm{Ti}$ with different compositions, which were prepared at $450^{\circ} \mathrm{C}$ and measured in both deaerated $0.1 \mathrm{M} \mathrm{HClO}_{4}$ (broken lines) and in $\mathrm{O}_{2}$-saturated $0.1 \mathrm{M} \mathrm{HClO}_{4}$ (solid lines) at $60^{\circ} \mathrm{C}$. The ORR behavior of some of these binary oxide-coated electrodes, along with those of the single oxide-coated electrodes, $\mathrm{TiO}_{x} / \mathrm{Ti}, \mathrm{ZrO}_{x} / \mathrm{Ti}$, and $\mathrm{TaO}_{x} / \mathrm{Ti}$, are shown in Fig. 12. The electrocatalytic activity is presented as mass-current density. Although the $\mathrm{TiO}_{x} / \mathrm{Ti}$ electrode gave the highest mass activity among these oxide-coated electrodes, as shown in Fig.12, the catalytic activity will be discussed with the surface-specific activity. As presented in Table 2, the addition of $\mathrm{TiO}_{x}$ to $\mathrm{ZrO}_{x}$ resulted in an increase in pseudocapacitance, while its addition to $\mathrm{TaO}_{x}$ resulted in a slight decrease in capacitance. The catalytic activity presented by $j_{\mathrm{SA}, 0.7}$ of these binary oxide electrodes is shown in Figs. 13 and 14. An evident increase in both specific activity and $E_{\mathrm{ORR}}$ by the formation of binary oxide was observed at the $\mathrm{Ti}_{0.7} \mathrm{Zr}_{0.3} \mathrm{O}_{x} / \mathrm{Ti}$ electrode. The $j_{\mathrm{SA}, 0.7}$ of this electrode, $12.5 \mathrm{~mA} \mathrm{~F}^{-1}$ (oxide), gave values 2.0 and 1.7 times higher than those of $\mathrm{TiO}_{x} / \mathrm{Ti}$ and $\mathrm{ZrO}_{x} / \mathrm{Ti}$, respectively.

$\mathrm{TiO}_{2}-\mathrm{ZrO}_{2}$ binary oxides, not only in mixed states but also as a solid solution such as $\mathrm{TiZrO}_{2}$, are well-known catalysts or catalyst support materials except in the research field of electrocatalysis [28]. Various preparation methods, 
characterizations and applications to catalysis processes, such as dehydrogenation, partial or deep oxidation and hydrogenation, have thus far been reported. The control of acidity within the content is important in designing catalysts and catalyst support materials. The acidity of this binary oxide as a function of the content reported by Wang and his coworkers [29] showed a volcano-type pattern with a maximum value at $50 \mathrm{~mol} \%$ of $\mathrm{TiO}_{2}$. Although we had expected that some relationship existed between the acidity and the oxide content of this binary oxide, no clear relationship was found in the specific activity. In addition to the acidity, the specific activity of $\mathrm{TiO}_{x} / \mathrm{Ti}$ was enhanced by the addition of $30 \mathrm{~mol} \%$ of $\mathrm{ZrO}_{x}$, while that of $\mathrm{ZrO}_{x}$ was reduced by the addition of $30 \mathrm{~mol} \%$ of $\mathrm{TiO}_{x}$. A detailed investigation into the effects of structure, morphology, and acidity on the catalytic behavior of this binary oxide is presently underway.

\subsection{ORR activity of $\mathrm{TaO}_{x}$ powder prepared from the dip-coating solution}

As an extension of the dip-coating method, tantalum oxide powder was prepared from the dip-coating solution of the butanolic solution of $\mathrm{TaCl}_{5}$. The specific surface area of the $\mathrm{TaO}_{x}$ powder calcined at $450{ }^{\circ} \mathrm{C}$ was $4.2 \mathrm{~m}^{2} \mathrm{~g}^{-1}$. The X-ray diffraction pattern of the powder, shown in Fig. 15, gave very broad diffraction peaks at the same diffraction angles from $\mathrm{TaO}_{x} / \mathrm{Ti}$ electrode. As assigned for the oxide-coated electrode, this powder sample might be $\mathrm{TaO}_{2}$ or something like that. The $\mathrm{Ta}_{4} \mathrm{f}_{7 / 2}$ peak from this powder sample appeared at 26.0 $\mathrm{eV}$, suggesting that the valency of the tantalum ions of this oxide was lower than that of $\mathrm{Ta}^{5+}(26.5 \mathrm{eV})$. The XPS analysis revealed that this $\mathrm{TaO}_{x}$ powder contained traces of titanium species less than $0.3 \%$. As shown in the hydrodynamic voltammograms (Fig. 16), the $\mathrm{TaO}_{x}$ powder provided high ORR 
current density; the ORR onset potential, $E_{\mathrm{ORR}}$, and the ORR current density at 0.7 vs. RHE, $j_{\mathrm{m}, 0.7}$, were $0.90 \mathrm{~V}$ vs. RHE and $12 \mathrm{~mA} \mathrm{~g}_{(\mathrm{TaO} x)}^{-1}$ at $60^{\circ} \mathrm{C}$, respectively. The $12 \mathrm{~mA} \mathrm{~g}^{-1}$ (TaOx) for the ORR mass current density of the powder catalyst at $0.7 \mathrm{~V}$ vs. RHE was similar in value, $10 \mathrm{~mA} \mathrm{~g}_{(\mathrm{TaO} x)}^{-1}$, as determined for the $\mathrm{TaO}_{x} / \mathrm{Ti}$ electrode prepared by the dip-coating method at the same calcination temperature, $450^{\circ} \mathrm{C}$ (Table 2). Figure 17 shows that the ORR current density of the carbon black added to the $\mathrm{TaO}_{x}$ powder was very low compared to the electrode of $\left(\mathrm{TaO}_{x}+\right.$ carbon black $)$.

Although the high ORR catalytic activity of tantalum oxynitrides and related compounds has already been reported by other research groups [16-20], significantly high activity of $\mathrm{TaO}_{x}$ containing no nitrogen or carbon for the reaction has not yet been reported. The $E_{\mathrm{ORR}}$ of the $\mathrm{Ta}_{2} \mathrm{O}_{5}$ powder prepared at $1000^{\circ} \mathrm{C}$ by Ota's research group was about $0.5 \mathrm{~V}$ vs. RHE. The large difference in value between the $E_{\mathrm{ORR}}$ of tantalum oxide prepared by Ota's group and that in this work was likely due to the differences in preparation methods and temperatures. Since the oxide ion vacancies may contribute to ORR, a detailed examination on the characteristics of tantalum oxide is necessary to clarify the active site and its stability.

\section{Conclusions}

In our search for inexpensive candidate oxide cathode catalysts for PEFCs, we investigated the electrocatalytic oxygen reduction reaction (ORR) of several valve metal $(\mathrm{Ti}, \mathrm{Zr}, \mathrm{Ta})$ oxide coatings prepared on a titanium substrate by the dip-coating method between $400^{\circ} \mathrm{C}$ and $500^{\circ} \mathrm{C}$ (typically $450^{\circ} \mathrm{C}$ ). The ORR onset potentials, $E_{\mathrm{ORR}}$, of $\mathrm{TiO}_{x}, \mathrm{ZrO}_{x}$ and $\mathrm{TaO}_{x}$ prepared at $450^{\circ} \mathrm{C}$ were 0.91 , 
0.81 , and $0.82 \mathrm{~V}$ vs. RHE at $60^{\circ} \mathrm{C}$, respectively. The catalytic activity of $\mathrm{TaO}_{x} / \mathrm{Ti}$ evaluated by ORR current density at $0.7 \mathrm{~V}$ vs. RHE, $j_{\text {geo, } 0.7}$, was $1.8 \mu \mathrm{A}$ $\mathrm{cm}^{-2}$ (geometric). To enhance the catalytic activity of $\mathrm{TiO}_{x}, \mathrm{ZrO}_{x}$, and $\mathrm{TaO}_{x}$ electrodes, $\mathrm{Ti}-\mathrm{Zr}-\mathrm{O} / \mathrm{Ti}$ and $\mathrm{Ti}-\mathrm{Ta}-/ \mathrm{Ti}-\mathrm{O} / \mathrm{Ti}$ binary oxide electrodes were investigated, and an enhancement of the catalytic activity was found at the $\mathrm{Ti}_{0.7} \mathrm{Zr}_{0.3} \mathrm{O}_{x} / \mathrm{Ti}$ and $\mathrm{Ti}_{0.5} \mathrm{Ta}_{0.5} \mathrm{O}_{x} / \mathrm{Ti}$ electrodes, although the extent was not highly significant. Finally, $\mathrm{TaO}_{x}$ powder prepared from the dip-coating solution at $450^{\circ} \mathrm{C}$ showed ORR catalytic activity, $j_{\mathrm{m}, 0.7}$, similar to that of the $\mathrm{TaO}_{x} / \mathrm{Ti}$ electrode. The $E_{\mathrm{ORR}}$ and the ORR current density at $0.7 \mathrm{~V}$ vs. RHE, $j_{\mathrm{m}, 0.7}$, of the $\mathrm{TaO}_{x}$ powder were $0.90 \mathrm{~V}$ vs. RHE and $12 \mathrm{~mA} \mathrm{~g}^{-1}$ (TaOx) at $30^{\circ} \mathrm{C}$, respectively. However, the $\mathrm{TiO}_{x}$ powder was prepared at a temperature considerably lower than those for $\mathrm{TaNO}_{x}$ and related powder catalysts reported to date. A detailed examination on the characteristics of tantalum oxide is necessary to clarify the active site and its stability.

\section{Acknowledgments}

This work was supported in part by the "Polymer Electrolyte Fuel Cell Program; Development of Next Generation Technology" project of the New Energy and Industrial Technology Development Organization (NEDO) of Japan.

\section{References}

[1] S. Suzuki, Y. Ohbu, T. Mizutani, Y. Takamori, M. Morishima, H. Daimon, M. Hiratani, J. Electrochem. Soc. 156 (2009) B27.

[2] J. S. Zheng, M. X. Wang, X. S. Zhang, Y. X. Wu, P. Li, X. G. Zhou, W. K. Yuan, J. Power Sources 175 (2008) 211. 
[3] X. W. Yu, S. Y. Ye, J. Power Sources 172 (2007) 145.

[4] V. R. Stamenkovic, B. Fowler, B. S. Mun, G. Wang, P. N. Ross, C. A. Lucas, N. Markovic, Science 315 (2007) 493.

[5] R. Bashyam, P. Zelenay, Nature 443 (2006) 63.

[6] Y. Liu, A. Ishihara, S. Mitsushima, K. Kamiya, K. Ota, Electrochem. Solid-State Lett. 8 (2005) A400.

[7] Y. Liu, A. Ishihara, S. Mitsushima, N. Kamiya, K. Ota, J. Electrochem. Soc., 154 (2007) B664.

[8] Y. Takasu, N. Yoshinaga, W. Sugimoto, Electrochem. Commun. 10 (2008) 668.

[9] N. Yoshinaga, W. Sugimoto, Y. Takasu, Electrochim. Acta 54 (2008) 566.

[10] M. Nie, P. K. Shen, M. Wu, Z. D. Wei, H. Meng, J. Power Sources $162(2006) 173$.

[11] A. M. Lazarin, C. A. Borgo, Y. Gushikem, J. Membr. Sci. 221 (2003) 175.

[12] B. Winther-Jensen, O. Winther-Jensen, M. Forsyth, D. R. MacFarlane, Science 321 (2008) 671.

[13] K. P. Gong, F. Du, Z. H. Xia, M. Durstock, L. M. Dai, Science 760 (2009) 323.

[14] C. Chritenn, G. Steinhilber, M. Schulze, K. A. Friedlich, J. Appl. Electrochem. 37 (2007) 1463.

[15] A. Takagaki, Y. Takahashi, F. Yin, K. Takanabe, J. Kubota, K. Domen, J. Electrochem. Soc. 156 (2009) B811. 
[16] A. Ishihara, K. Lee, S. Doi, S. Mitsushima, N. Kamiya, M.Hara, K. Domen, K. Fukuda, K. Ota, Electrochem. Solid-State Lett. 8 (2005) A201.

[17] A. Ishihara, S. Doi, S. Mitsushima, K. Ota, Electrochim. Acta 53 (2008) 5442.

[18] J.-H. Kim, A. Ishihara, S. Mitsushima, N. Kamiya, K. Ota, Electrochemistry 75 (2007) 166.

[19] A. Ishihara, Y. Shibata, S. Mitsushima, K. Ota, J. Electrochem. Soc. 155 (2008) B400.

[20] Y. Ohgi, A. Ishihara, Y. Shibata, S. Mitsushima, K. Ota, Chem. Lett. 37 (2008) 608.

[21] K.-D. Nam, A. Ishihara, K. Matsuzawa, S. Mitsushima, K. Ota, Electrochem. Solid-State Lett. 12 (2009) B158.

[22] J. Rolewicz, Ch. Comminellis, E. Plattner, J. Hinden, Chimia 42 (1988) 75.

[23] J. Rolewicz, Ch. Comminellis, E. Plattner, J. Hinden, Electrochim. Acta 33 (1988) 573.

[24] S. Trasatti, Electrochim. Acta 45 (2000) 2377.

[25] K. Kameyama, K. Tsukada, K. Yahikozawa, Y. Takasu, J. Electrochem. Soc. 141 (1994) 643.

[26] T. J. Schmidt, M. Noeske, H. A. Gasteiger, R. J. Behm, P. Britz, H. J. Bönnemann, J. Electrochem. Soc. 145 (1998) 925.

[27] T. J. Schmidt, H. A. Gasteiger, G. D. Stäb, P. M. Urban, D. M. Kolb, R. J. Behm, J. Electrochem. Soc. 145 (1998) 2354.

[28] B. M. Reddy, A. Khan, Catalysis Reviews, 47 (2005) 257.

[29] I. Wang, W.F. Chang, R.J. Shiau, J.C. Wu, C.S. Chung, J. Catal. 83 
(1983) 428.

\section{Figure captions}

Fig. 1 SEM micrographs of the $\mathrm{TiO}_{x} / \mathrm{Ti}, \mathrm{ZrO}_{x} / \mathrm{Ti}$, and $\mathrm{TaO}_{x} / \mathrm{Ti}$ electrodes prepared by dip-coating method at $450^{\circ} \mathrm{C}$ (at low magnification) Electrode: (a) $\mathrm{TiO}_{x} / \mathrm{Ti}$, (b) $\mathrm{ZrO}_{x} / \mathrm{Ti}$, (c) $\mathrm{TaO}_{x} / \mathrm{Ti}$

Fig. $2 \mathrm{SEM}$ micrographs of the $\mathrm{TiO}_{x} / \mathrm{Ti}, \mathrm{ZrO}_{x} / \mathrm{Ti}$, and $\mathrm{TaO}_{x} / \mathrm{Ti}$ electrodes prepared by dip-coating method at $450^{\circ} \mathrm{C}$ (at higher magnifications)

Electrode: (a-1) and (a-2) $\mathrm{TiO}_{x} / \mathrm{Ti},(\mathrm{b}-1)$ and (b-2); $\mathrm{ZrO}_{x} / \mathrm{Ti}$, (c-1) and (c-2) $\mathrm{TaO}_{x} / \mathrm{Ti}$

Fig. 3 A comparison of the surface morphology of the pristine $\mathrm{ZrO}_{x} / \mathrm{Ti}$ electrode and that of after the polarization.

Treatment: (a-1) and (a-2); pristine, (b-1) and (b-2); after the electrochemical measurement as described in section 2.3.

Fig. 4 SEM micrographs of the Ti-Zr-O/Ti binary electrodes prepared by dip-coating method at $450^{\circ} \mathrm{C}$

Electrode: (a) $\mathrm{Ti}_{0.7} \mathrm{Zr}_{0.3} \mathrm{O}_{x} / \mathrm{Ti}$, (b) $\mathrm{Ti}_{0.5} \mathrm{Zr}_{0.5} \mathrm{O}_{x} / \mathrm{Ti}$, (c) $\mathrm{Ti}_{0.3} \mathrm{Zr}_{0.7} \mathrm{O}_{x} / \mathrm{Ti}$

Fig. 5 SEM micrographs of the Ti-Ta-O/Ti binary electrodes prepared by dip-coating method at $450^{\circ} \mathrm{C}$

Electrode: (a) $\mathrm{Ti}_{0.7} \mathrm{Ta}_{0.3} \mathrm{O}_{x} / \mathrm{Ti}$, (b) $\mathrm{Ti}_{0.5} \mathrm{Ta}_{0.5} \mathrm{O}_{x} / \mathrm{Ti}$, (c) $\mathrm{Ti}_{0.3} \mathrm{Ta}_{0.7} \mathrm{O}_{x} / \mathrm{Ti}$ 
Fig. 6 XRD patterns for the various oxide-coated electrodes prepared by dip-coating method at $450^{\circ} \mathrm{C}$

Electrode: (a) $\mathrm{TiO}_{x} / \mathrm{Ti}$, (b) $\mathrm{ZrO}_{x} / \mathrm{Ti}$, (c) $\mathrm{TaO}_{x} / \mathrm{Ti}$, (d) $\mathrm{Ti}_{0.7} \mathrm{Zr}_{0.3} \mathrm{O}_{x} / \mathrm{Ti}$, (e) $\mathrm{Ti}_{0.5} \mathrm{Zr}_{0.5} \mathrm{O}_{x} / \mathrm{Ti}$ ，(f) $\mathrm{Ti}_{0.3} \mathrm{Zr}_{0.7} \mathrm{O}_{x} / \mathrm{Ti}$ ，(g) $\mathrm{Ti}_{0.7} \mathrm{Zr}_{0.3} \mathrm{O}_{x} / \mathrm{Ti}$ ，(h) $\mathrm{Ti}_{0.5} \mathrm{Zr}_{0.5} \mathrm{O}_{x} / \mathrm{Ti}$ ， (i) $\mathrm{Ti}_{0.3} \mathrm{Zr}_{0.7} \mathrm{O}_{x} / \mathrm{Ti}$

Fig. 7 XPS spectra of Ti2p and Zr3d from the Ti-Zr-O/Ti binary electrodes prepared by dip-coating method at $450^{\circ} \mathrm{C}$

Electrode: (a-1) and (a-2) $\mathrm{Ti}_{0.7} \mathrm{Zr}_{0.3} \mathrm{O}_{x} / \mathrm{Ti}$, (b-1) and (b-2) $\mathrm{Ti}_{0.3} \mathrm{Zr}_{0.7} \mathrm{O}_{x} / \mathrm{Ti}$

Fig. 8 XPS spectra of Ti2p and Ta4f from the Ti-Ta-O/Ti binary electrodes prepared by dip-coating method at $450^{\circ} \mathrm{C}$

Electrode: (a-1) and (a-2) $\mathrm{Ti}_{0.7} \mathrm{Ta}_{0.3} \mathrm{O}_{x} / \mathrm{Ti}$, (b-1) and (b-2) $\mathrm{Ti}_{0.3} \mathrm{Ta}_{0.7} \mathrm{O}_{x} / \mathrm{Ti}$

Fig. 9 Cyclic voltammograms of the $\mathrm{TiO}_{x} / \mathrm{Ti}, \mathrm{ZrO}_{x} / \mathrm{Ti}$, and $\mathrm{TaO}_{x} / \mathrm{Ti}$ electrodes prepared by dip-coating method at $450^{\circ} \mathrm{C}$

Electrode: (a) $\mathrm{TiO}_{x} / \mathrm{Ti}$, (b) $\mathrm{ZrO}_{x} / \mathrm{Ti}$, (c) $\mathrm{TaO}_{x} / \mathrm{Ti}$

Electrolyte: Broken lines - in deaerated $0.1 \mathrm{M} \mathrm{HClO}_{4}$ with $\mathrm{N}_{2}$ at $60^{\circ} \mathrm{C}$; Solid lines - in $\mathrm{O}_{2}$-saturated $0.1 \mathrm{M} \mathrm{HClO}_{4}$ at $60^{\circ} \mathrm{C}$

Electrode potential sweep rate: $5 \mathrm{mV} \mathrm{s}^{-1}$

Fig. 10 Cyclic voltammograms of the Ti-Zr-O/Ti binary electrodes prepared by dip-coating method at $450^{\circ} \mathrm{C}$

Electrode: (a) $\mathrm{Ti}_{0.7} \mathrm{Zr}_{0.3} \mathrm{O}_{x} / \mathrm{Ti}$, (b) $\mathrm{Ti}_{0.5} \mathrm{Zr}_{0.5} \mathrm{O}_{x} / \mathrm{Ti}$, (c) $\mathrm{Ti}_{0.3} \mathrm{Zr}_{0.7} \mathrm{O}_{x} / \mathrm{Ti}$

Electrolyte: Broken lines - in $\mathrm{O}_{2}$-purged 0.1 $\mathrm{M} \mathrm{HClO}_{4}$ with $\mathrm{N}_{2}$ at $60^{\circ} \mathrm{C}$; Solid 
lines - in $\mathrm{O}_{2}$-saturated $0.1 \mathrm{M} \mathrm{HClO}_{4}$ at $60^{\circ} \mathrm{C}$

Electrode potential sweep rate: $5 \mathrm{mV} \mathrm{s}^{-1}$

Fig. 11 Cyclic voltammograms of the Ti-Ta-O/Ti binary electrodes prepared by dip-coating method at $450^{\circ} \mathrm{C}$

Electrode: (a) $\mathrm{Ti}_{0.7} \mathrm{Ta}_{0.3} \mathrm{O}_{x} / \mathrm{Ti}$, (b) $\mathrm{Ti}_{0.5} \mathrm{Ta}_{0.5} \mathrm{O}_{x} / \mathrm{Ti}$, (c) $\mathrm{Ti}_{0.3} \mathrm{Ta}_{0.7} \mathrm{O}_{x} / \mathrm{Ti}$

Electrolyte: Broken lines - in $\mathrm{O}_{2}$-purged $0.1 \mathrm{M} \mathrm{HClO}_{4}$ with $\mathrm{N}_{2}$ at $60^{\circ} \mathrm{C}$; Solid lines - in $\mathrm{O}_{2}$-saturated $0.1 \mathrm{M} \mathrm{HClO}_{4}$ at $60^{\circ} \mathrm{C}$

Electrode potential sweep rate: $5 \mathrm{mV} \mathrm{s}^{-1}$

Fig. 12 ORR-current curves of the $\mathrm{TiO}_{x} / \mathrm{Ti}, \mathrm{ZrO}_{x} / \mathrm{Ti}, \mathrm{TaO}_{x} / \mathrm{Ti}$, Ti-Zr-O/Ti, and Ti-Ta-O/Ti binary electrodes prepared by dip-coating method at $450^{\circ} \mathrm{C}$

The ORR-current curves were drawn by deducting the voltammograms in the deaerated $\mathrm{HClO}_{4}$ solution from those of the $\mathrm{O}_{2}$-saturated solution presented in Figs. 9, 10 and 11.

Electrode: (a) $\mathrm{TiO}_{x} / \mathrm{Ti}$ (black), (b) $\mathrm{Ti}_{0.7} \mathrm{Zr}_{0.3} \mathrm{O}_{x} / \mathrm{Ti}$ (green), (c) $\mathrm{Ti}_{0.3} \mathrm{Ta}_{0.7} \mathrm{O}_{x} / \mathrm{Ti}$ (light blue), (d) $\mathrm{ZrO}_{x} / \mathrm{Ti}$ (red) and (e) $\mathrm{TaO}_{x} / \mathrm{Ti}$ (dark blue).

Fig. 13 ORR onset potential, $E_{\mathrm{ORR}}$, and ORR current density at $0.7 \mathrm{~V}$ vs. RHE, $j$, of the Ti-Zr-O/Ti electrodes

Open circles $-E_{\mathrm{ORR}}$; Solid circles $-j$.

Fig. 14 ORR onset potential, $E_{\mathrm{ORR}}$, and ORR current density at $0.7 \mathrm{~V}$ vs. RHE of the Ti-Ta-O/Ti electrodes

Open circles $-E_{\mathrm{ORR}}$; Solid circles $-j$. 
Fig. 15 The XRD pattern of the $\mathrm{TaO}_{x}$ powder calcined at $450^{\circ} \mathrm{C}$ for $30 \mathrm{~min}$

Fig. 16 Hydrodynamic voltammograms of the $\left(\mathrm{TaO}_{x}\right.$ particles + carbon black $)$ electrode rotated at $2000 \mathrm{rpm}$ with the RDE equipment.

Electrode: $\mathrm{TaO}_{x}$ (95 mass\%) mixed with carbon black (Vulcan XC-72R; 5 mass $\%$ ). $\mathrm{TaO}_{x}$ powder was prepared by calcination of the dried dip-coating solution at $450^{\circ} \mathrm{C}$ for 30 min. Loading amount of $\mathrm{TaO}_{x}$ on the $\mathrm{GC}$ (glassy carbon) surface of the working electrode of the RDE: $1 \mathrm{mg} \mathrm{cm}^{-2}$. Electrolyte: black line - in deaerated $0.1 \mathrm{M} \mathrm{HClO}_{4}$ with $\mathrm{N}_{2}$ at $30^{\circ} \mathrm{C}$; red line - in $\mathrm{O}_{2}$-saturated $0.1 \mathrm{M} \mathrm{HClO}_{4}$ at $30^{\circ} \mathrm{C}$. Electrode potential sweep rate: $5 \mathrm{mV} \mathrm{s}^{-1}$. Rotating speed of the test electrode in the RDE measurements: $2000 \mathrm{rpm}$.

Fig. 17 Hydrodynamic voltammograms of the electrode loading carbon black rotated at $2000 \mathrm{rpm}$ with the RDE equipment.

Electrode: carbon black (Vulcan XC-72R). Loading amount of carbon black powder on the GC (glassy carbon) surface of the working electrode of the RDE: $0.05 \mathrm{mg} \mathrm{cm}^{-2}$. Electrolyte: black line - in deaerated $0.1 \mathrm{M} \mathrm{HClO}_{4}$ with $\mathrm{N}_{2}$ at $30^{\circ} \mathrm{C}$; red line - in $\mathrm{O}_{2}$-saturated $0.1 \mathrm{M} \mathrm{HClO}_{4}$ at $30^{\circ} \mathrm{C}$. Electrode potential sweep rate: $5 \mathrm{mV} \mathrm{s}^{-1}$. Rotating speed of the test electrode in the RDE measurements: $2000 \mathrm{rpm}$. 
Table 1 Binding energy and content ratios of metal species of various oxide-coated electrodes determined by XPS (after the electrochemical measurement)

\begin{tabular}{|c|c|c|c|c|c|}
\hline \multirow[t]{2}{*}{ Electrode } & \multicolumn{3}{|c|}{ Binding energy/eV } & \multicolumn{2}{|c|}{ Content ratios } \\
\hline & $\operatorname{Ti} 2 \mathrm{p}_{3 / 2}$ & Zr 3d $d_{5 / 2}$ & Ta $4 f_{7 / 2}$ & $\mathrm{Ti}: \mathrm{Zr}$ & $\mathrm{Ti}: \mathrm{Ta}$ \\
\hline$\overline{\mathrm{TiO}_{x} / \mathrm{Ti}}$ & 458.0 & & & & \\
\hline $\mathrm{ZrO}_{x} / \mathrm{Ti}$ & & 181.7 & & & \\
\hline $\mathrm{TaO}_{x} / \mathrm{Ti}$ & & & 25.8 & & \\
\hline $\mathrm{Ti}_{0.7} \mathrm{Zr}_{0.3} \mathrm{O}_{x} / \mathrm{Ti}$ & 458.3 & 182.2 & & $39: 61$ & \\
\hline $\mathrm{Ti}_{0.3} \mathrm{Zr}_{0.7} \mathrm{O}_{x} / \mathrm{Ti}$ & 457.7 & 181.5 & & $23: 77$ & \\
\hline $\mathrm{Ti}_{0.7} \mathrm{Ta}_{0.3} \mathrm{O}_{x} / \mathrm{Ti}$ & 458.0 & & 25.7 & & $50: 50$ \\
\hline $\mathrm{Ti}_{0.3} \mathrm{Ta}_{0.7} \mathrm{O}_{x} / \mathrm{Ti}$ & 458.0 & & 25.5 & & $13: 87$ \\
\hline
\end{tabular}


Table 2 Electrochemical characteristics of various oxide-coated electrodes

\begin{tabular}{|c|c|c|c|c|c|}
\hline Electrode & $\begin{array}{c}E_{\mathrm{ORR}} \\
\text { vs. RHE / V }\end{array}$ & $\begin{array}{c}C_{\mathrm{pc}} \\
\mu \mathrm{F} \mathrm{cm}^{-2} \text { (geometric) }\end{array}$ & $\begin{array}{c}j_{(\text {geo) }, 0.7} \\
\mu \mathrm{A} \mathrm{cm}^{-2} \text { (geometric) }\end{array}$ & $\begin{array}{c}j_{\mathrm{SA}, 0.7} \\
\mathrm{~mA} \mathrm{~F}^{-1} \text { (oxide) }\end{array}$ & $\begin{array}{c}j_{\mathrm{m}, 0.7} \\
\mathrm{~mA} \mathrm{~g}^{-1}{ }_{\text {(oxide) }}\end{array}$ \\
\hline $\mathrm{TiO}_{x} / \mathrm{Ti}$ & 0.91 & 478 & 3.9 & 8.2 & 24 \\
\hline $\mathrm{ZrO}_{x} / \mathrm{Ti}$ & 0.81 & 274 & 2.0 & 7.3 & 11 \\
\hline $\mathrm{TaO}_{x} / \mathrm{Ti}$ & 0.82 & 284 & 1.8 & 6.3 & 10 \\
\hline $\mathrm{Ti}_{0.7} \mathrm{Zr}_{0.3} \mathrm{O}_{x} / \mathrm{Ti}$ & 0.86 & 287 & 3.6 & 12.5 & 21 \\
\hline $\mathrm{Ti}_{0.5} \mathrm{Zr}_{0.5} \mathrm{O}_{x} / \mathrm{Ti}$ & 0.85 & 297 & 1.7 & 5.7 & 10 \\
\hline $\mathrm{Ti}_{0.3} \mathrm{Zr}_{0.7} \mathrm{O}_{x} / \mathrm{Ti}$ & 0.76 & 373 & 1.0 & 2.7 & 5.6 \\
\hline $\mathrm{Ti}_{0.7} \mathrm{Ta}_{0.3} \mathrm{O}_{x} / \mathrm{Ti}$ & 0.90 & 415 & 2.1 & 5.1 & 12 \\
\hline $\mathrm{Ti}_{0.5} \mathrm{Ta}_{0.5} \mathrm{O}_{x} / \mathrm{Ti}$ & 0.81 & 196 & 2.3 & 11.7 & 13 \\
\hline $\mathrm{Ti}_{0.3} \mathrm{Ta}_{0.7} \mathrm{O}_{x} / \mathrm{Ti}$ & 0.84 & 279 & 2.7 & 9.7 & 17 \\
\hline
\end{tabular}

$E_{\text {ORR }}$ : Onset potential for the ORR at the cathodic potential sweep

$C_{\mathrm{pc}}$ : Pseudo-capacitance

$j_{\text {geo, } 0.7}$ : Current density for the ORR at $0.7 \mathrm{~V}$ vs. RHE per geometric surface area of the electrodes.

$j_{\mathrm{SA}, 0.7}$ : Current density for the ORR at $0.7 \mathrm{~V}$ vs. RHE divided by the pseudo-capacitance of the electrodes.

$j_{\mathrm{m}, 0.7}$ : Current density of the oxide-coated electrodes for the ORR at $0.7 \mathrm{~V}$ vs. RHE per mass of the oxide loaded on each Ti substrates. 

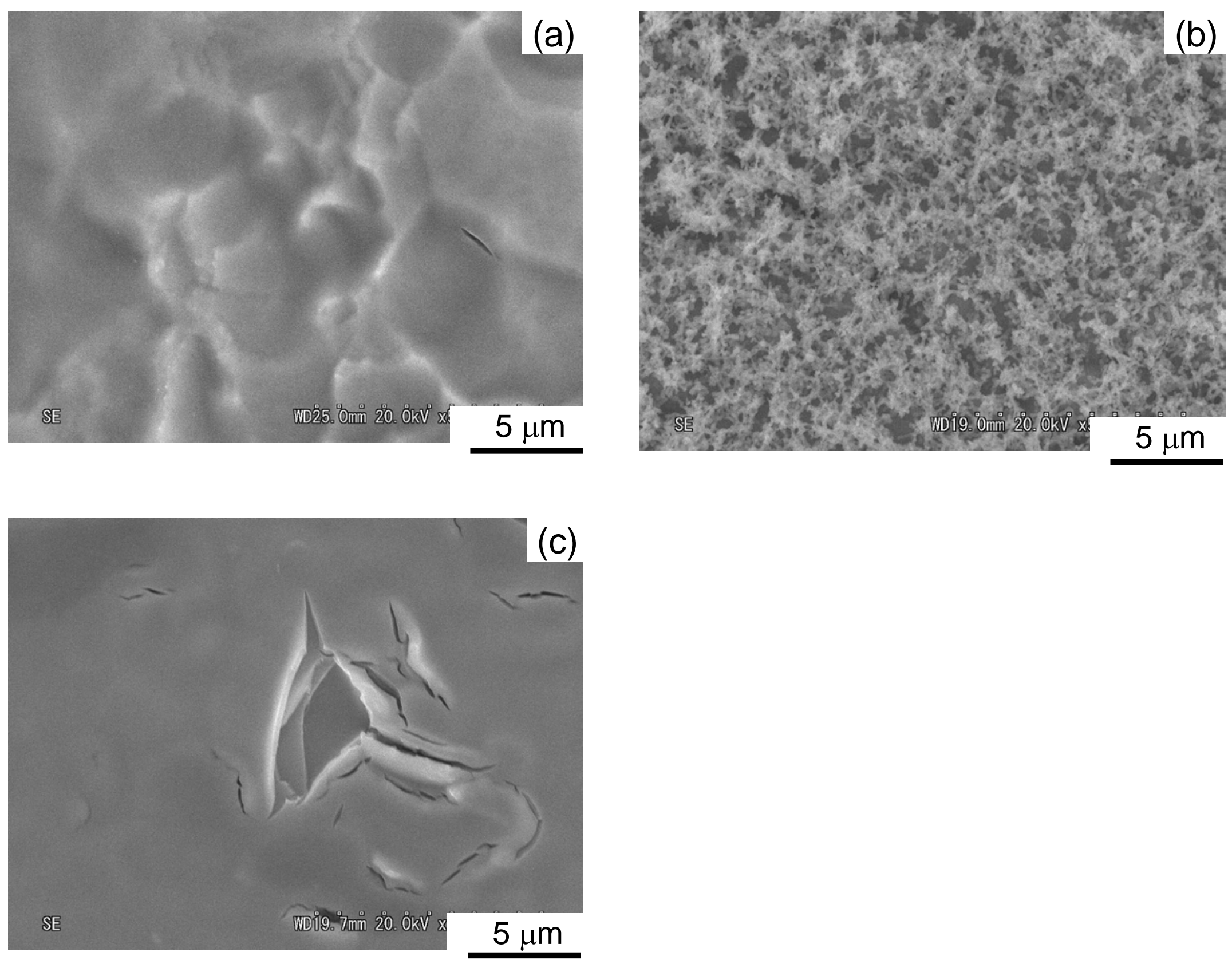

Fig. 1 Y. Takasu et al. 

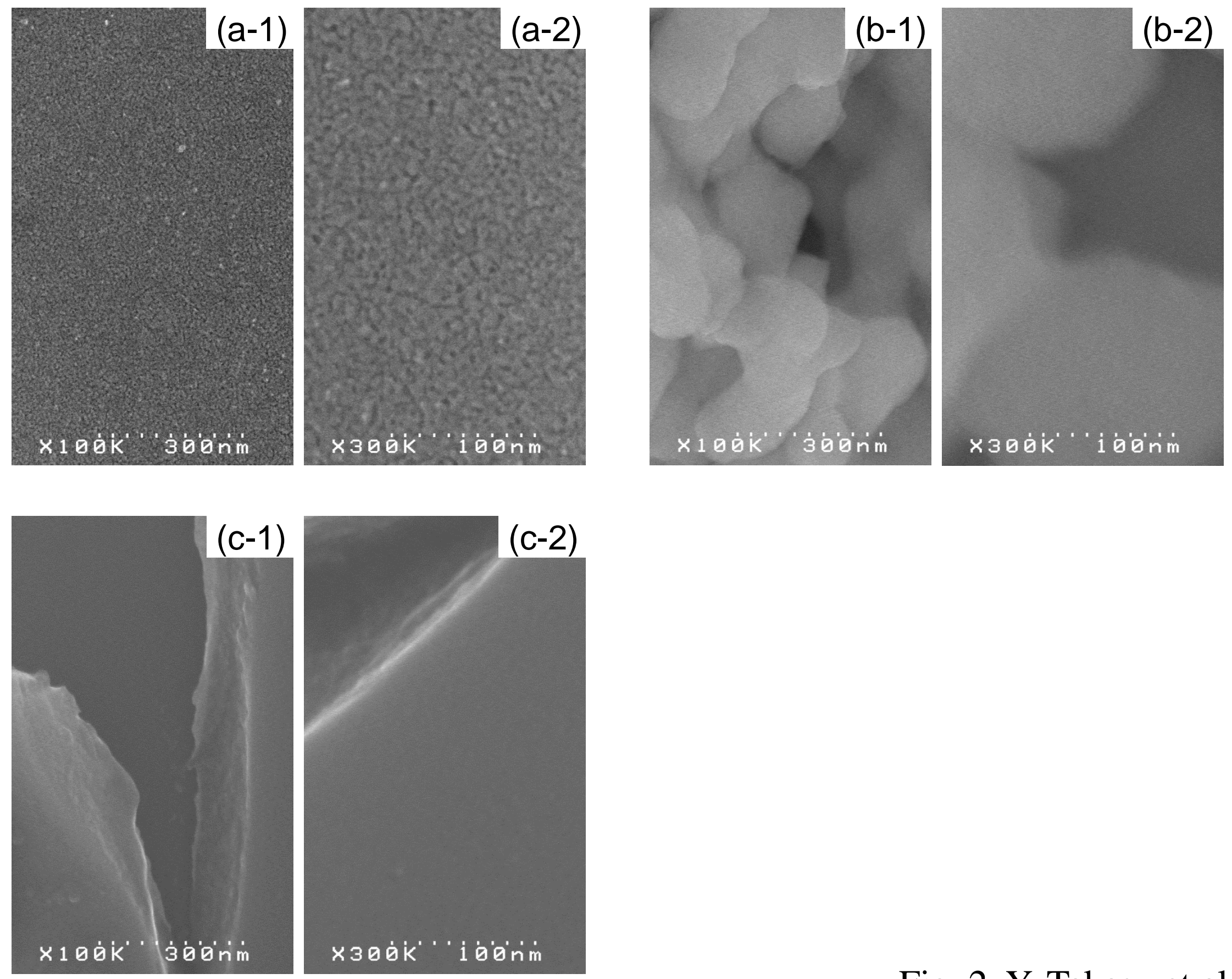

Fig. 2 Y. Takasu et al. 


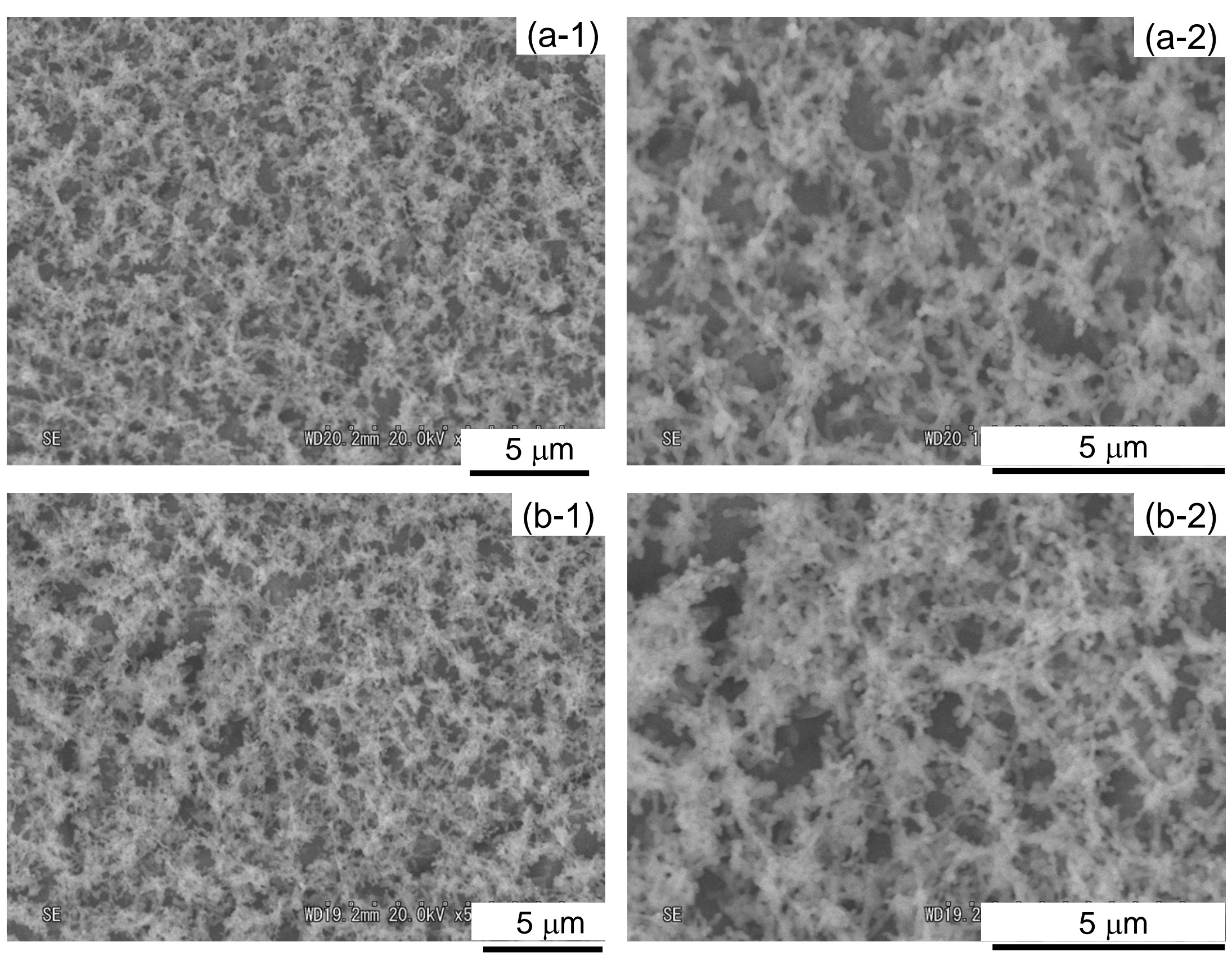

Fig. 3 Y. Takasu et al. 

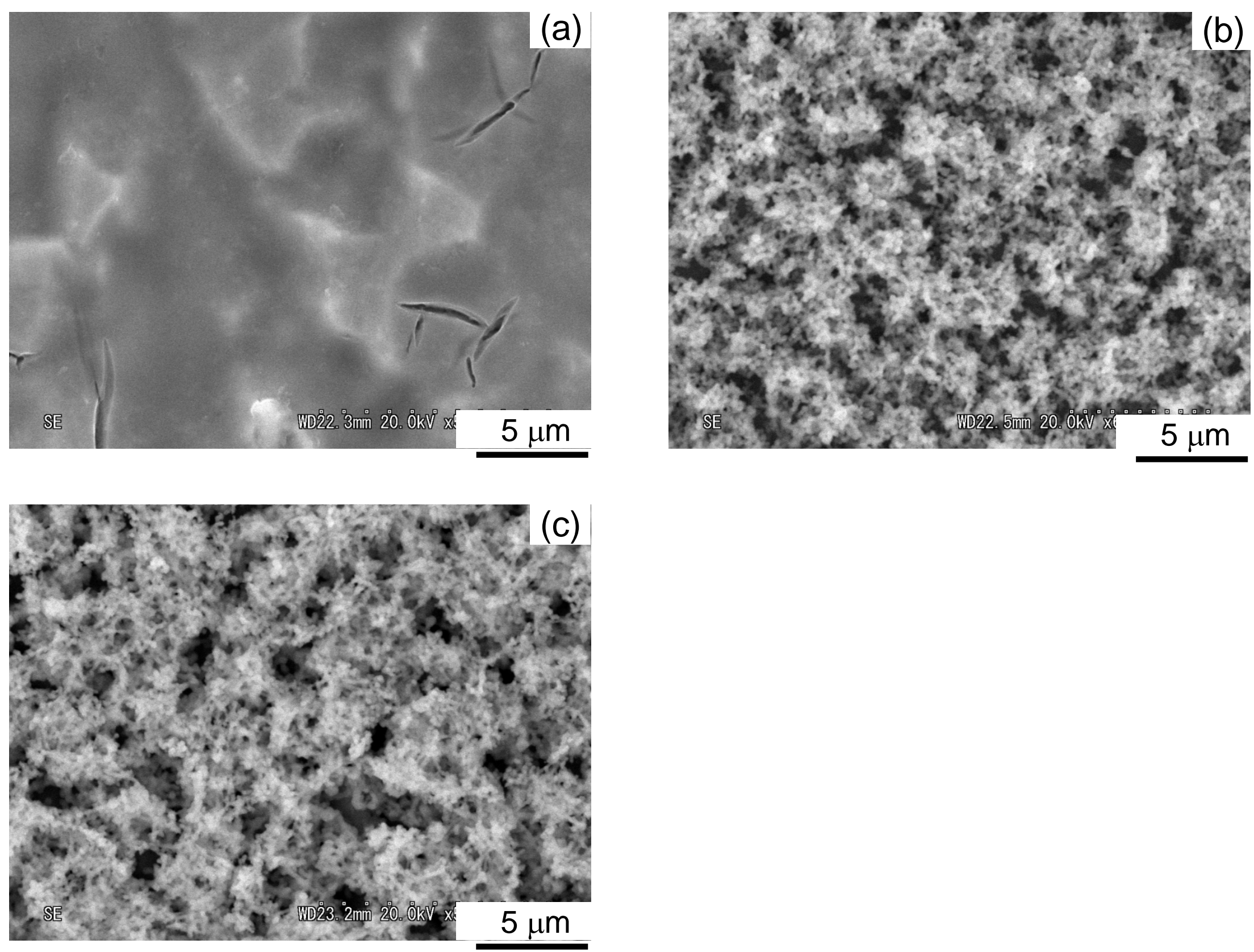

Fig. 4 Y. Takasu et al. 

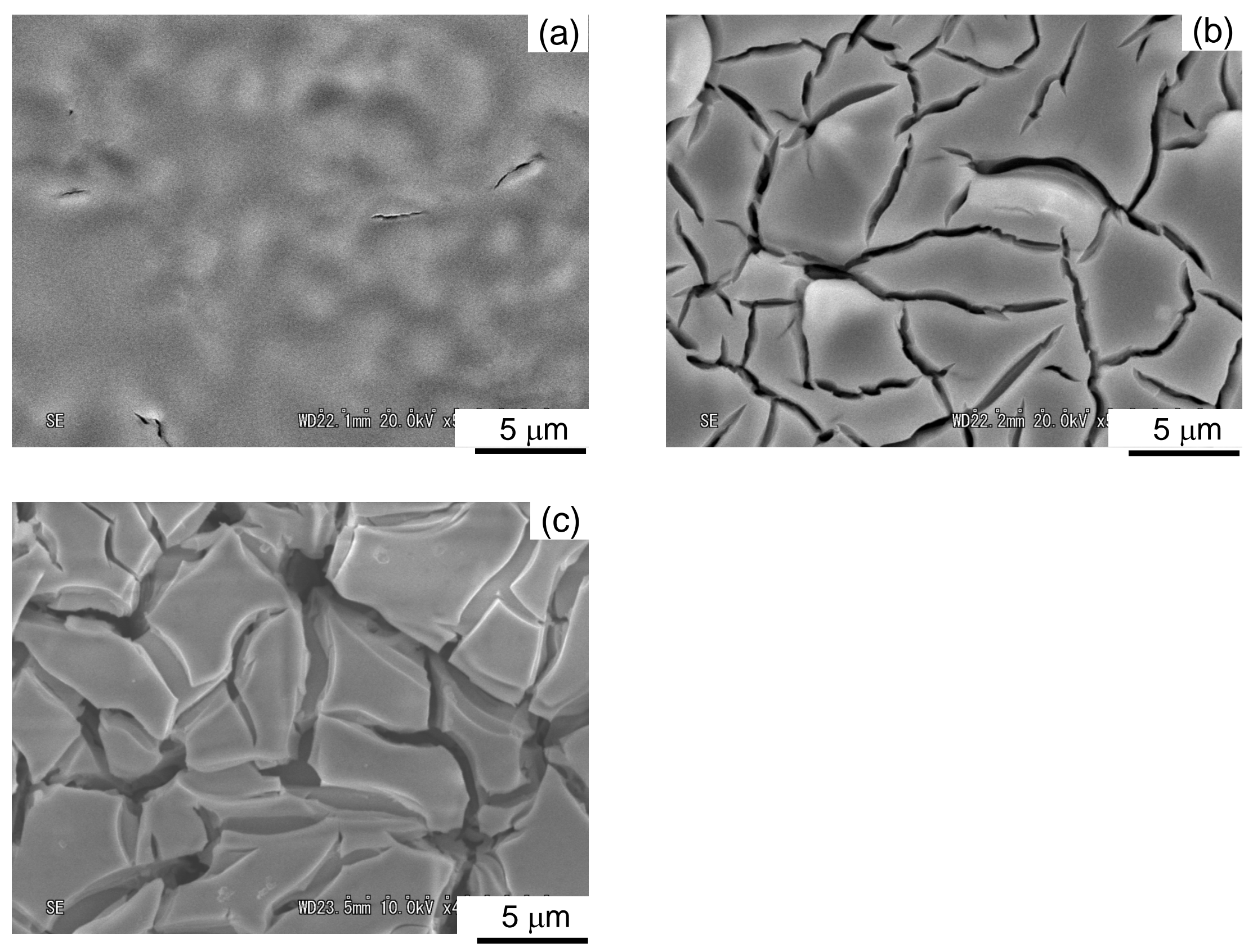

Fig. 5 Y. Takasu et al. 


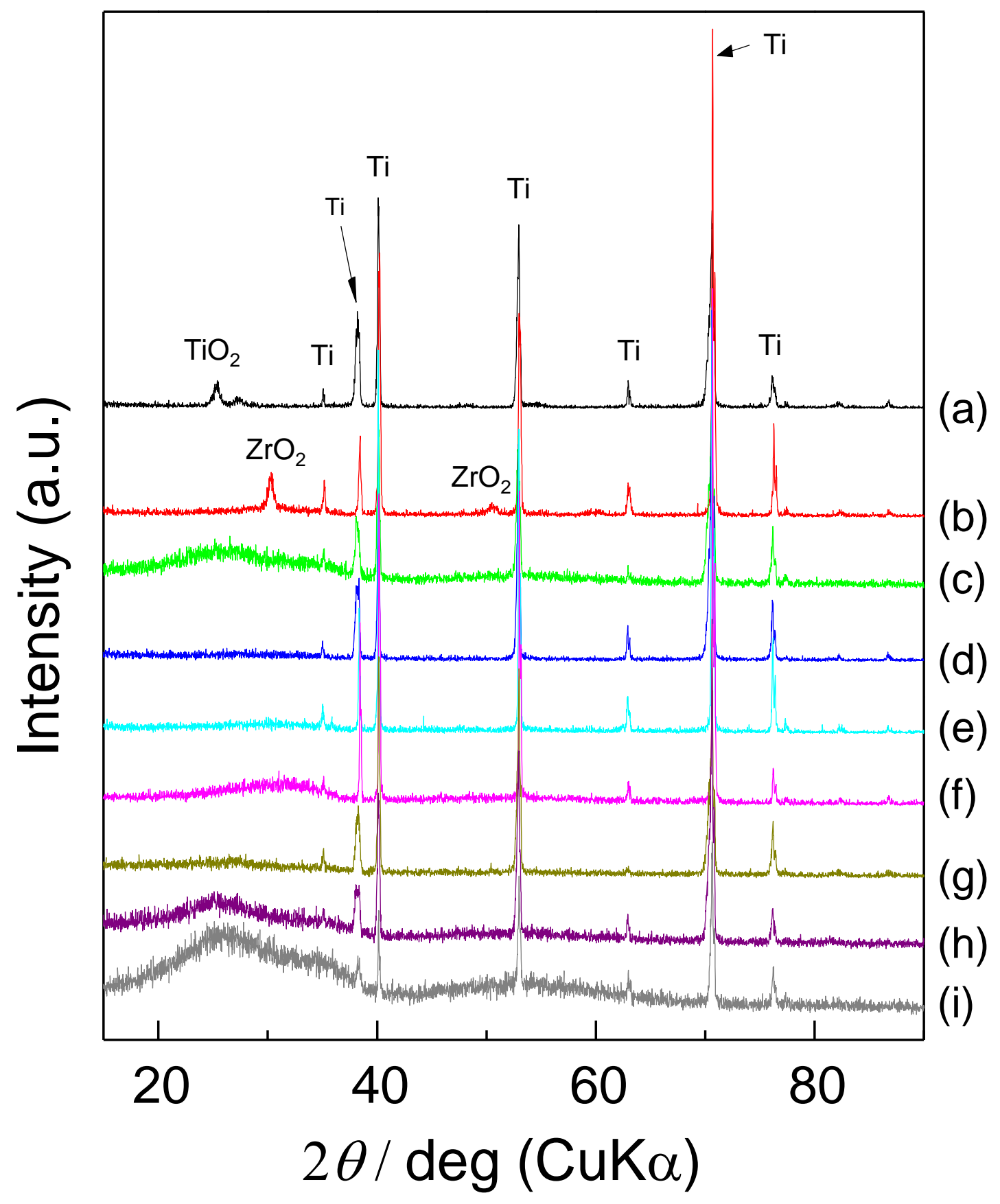

Fig. 6 Y. Takasu et al. 

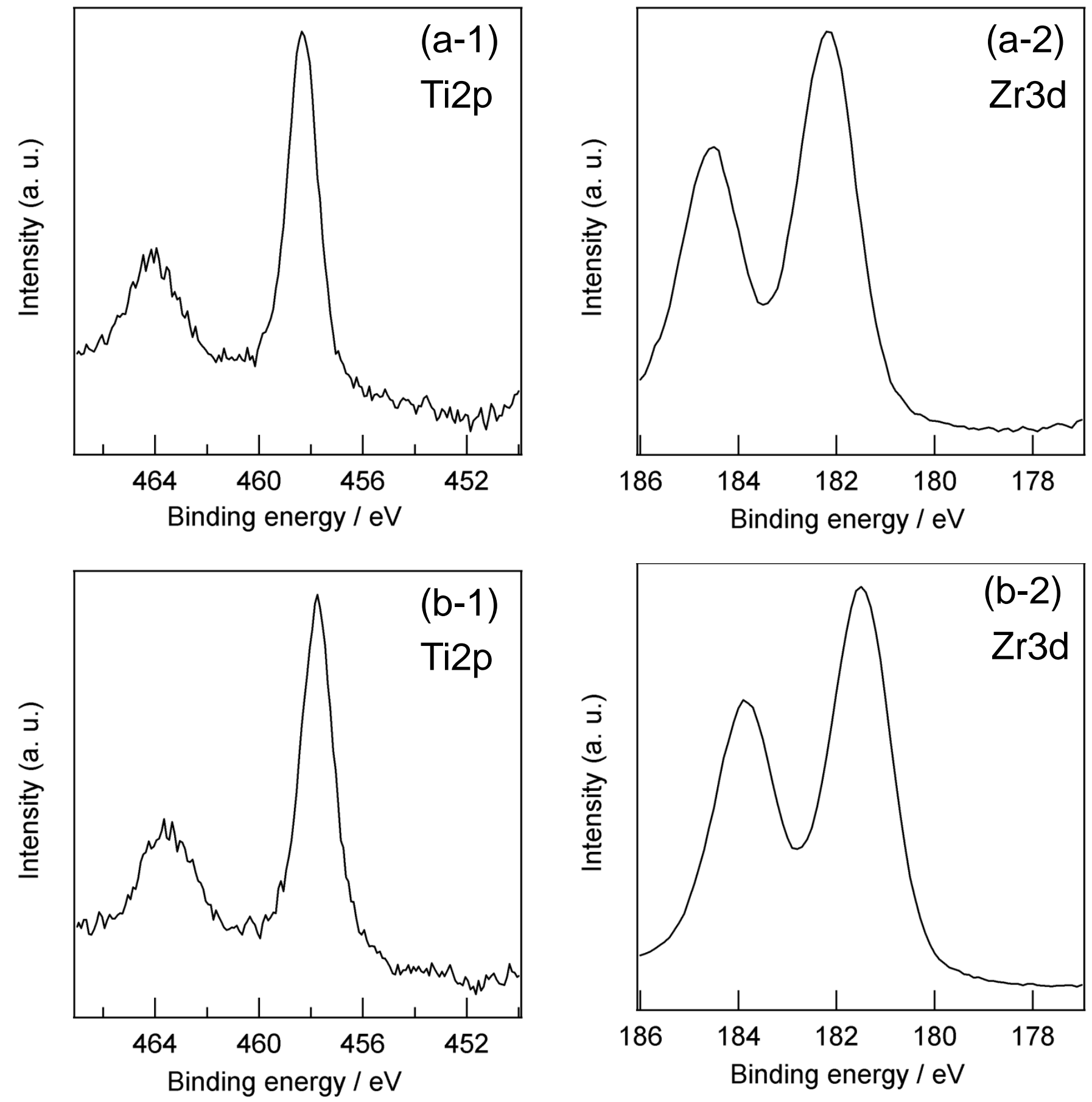

Fig. 7

Y. Takasu et al. 

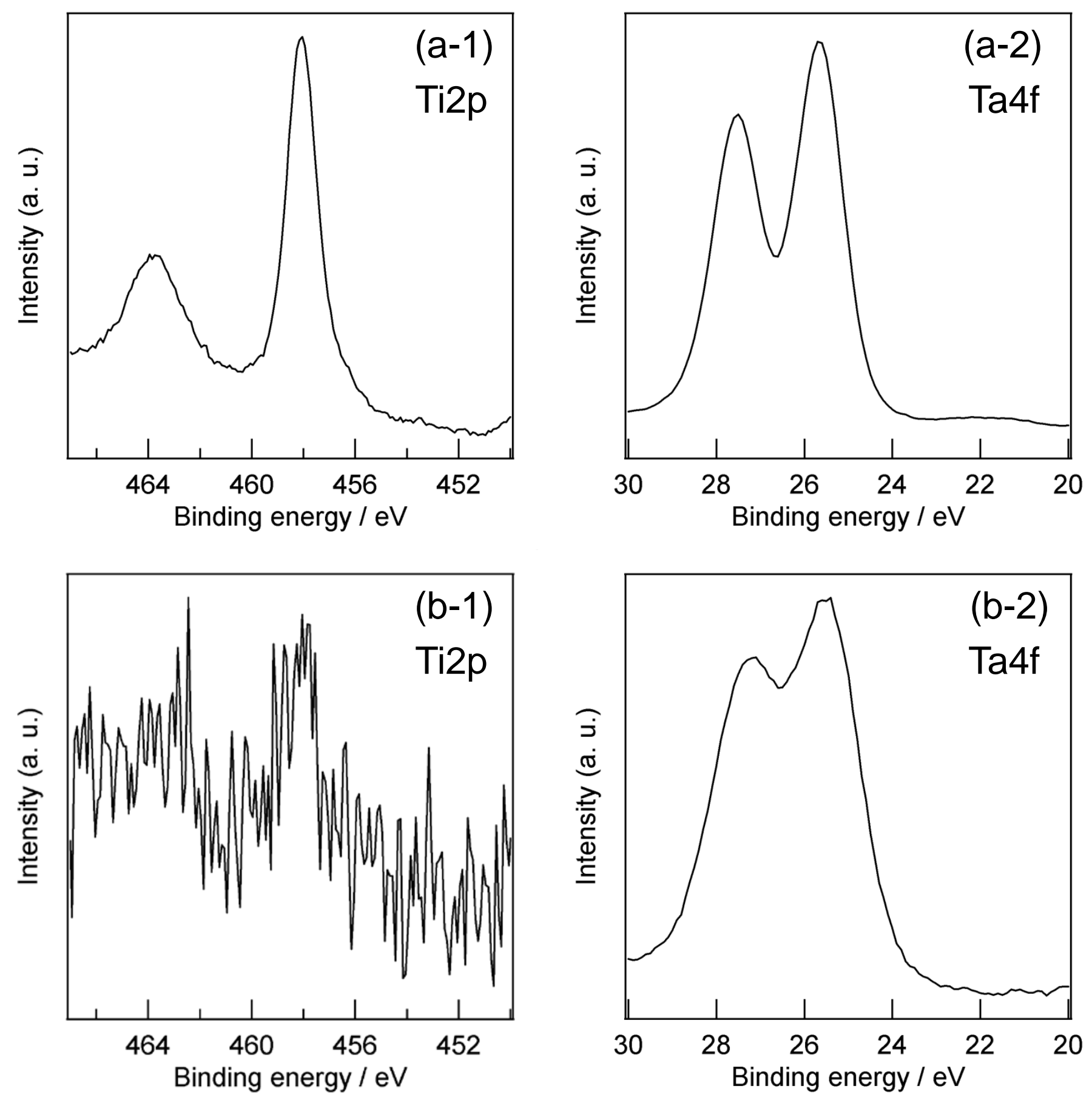

Fig. 8

Y. Takasu et al. 

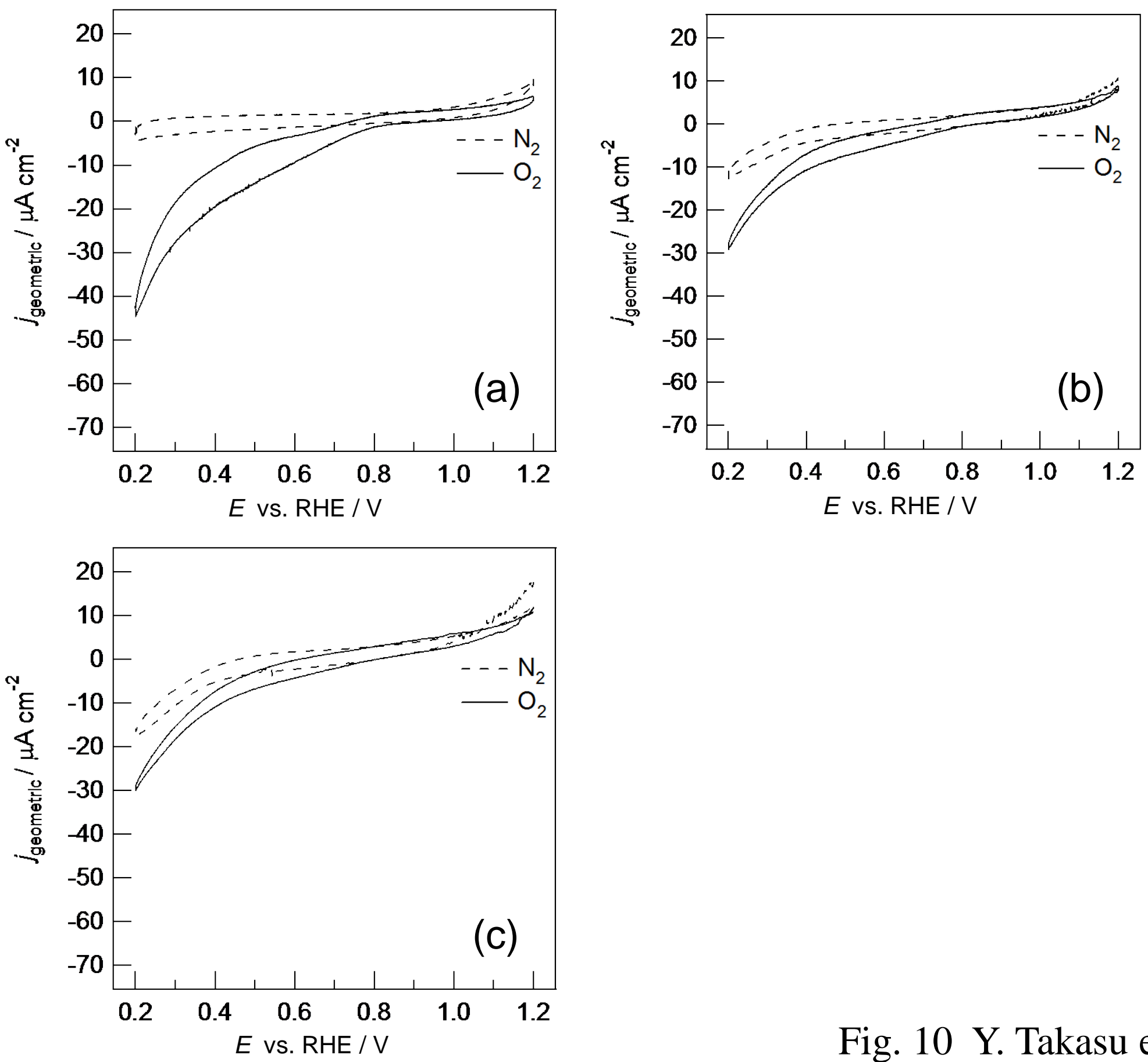

Fig. 10 Y. Takasu et al. 

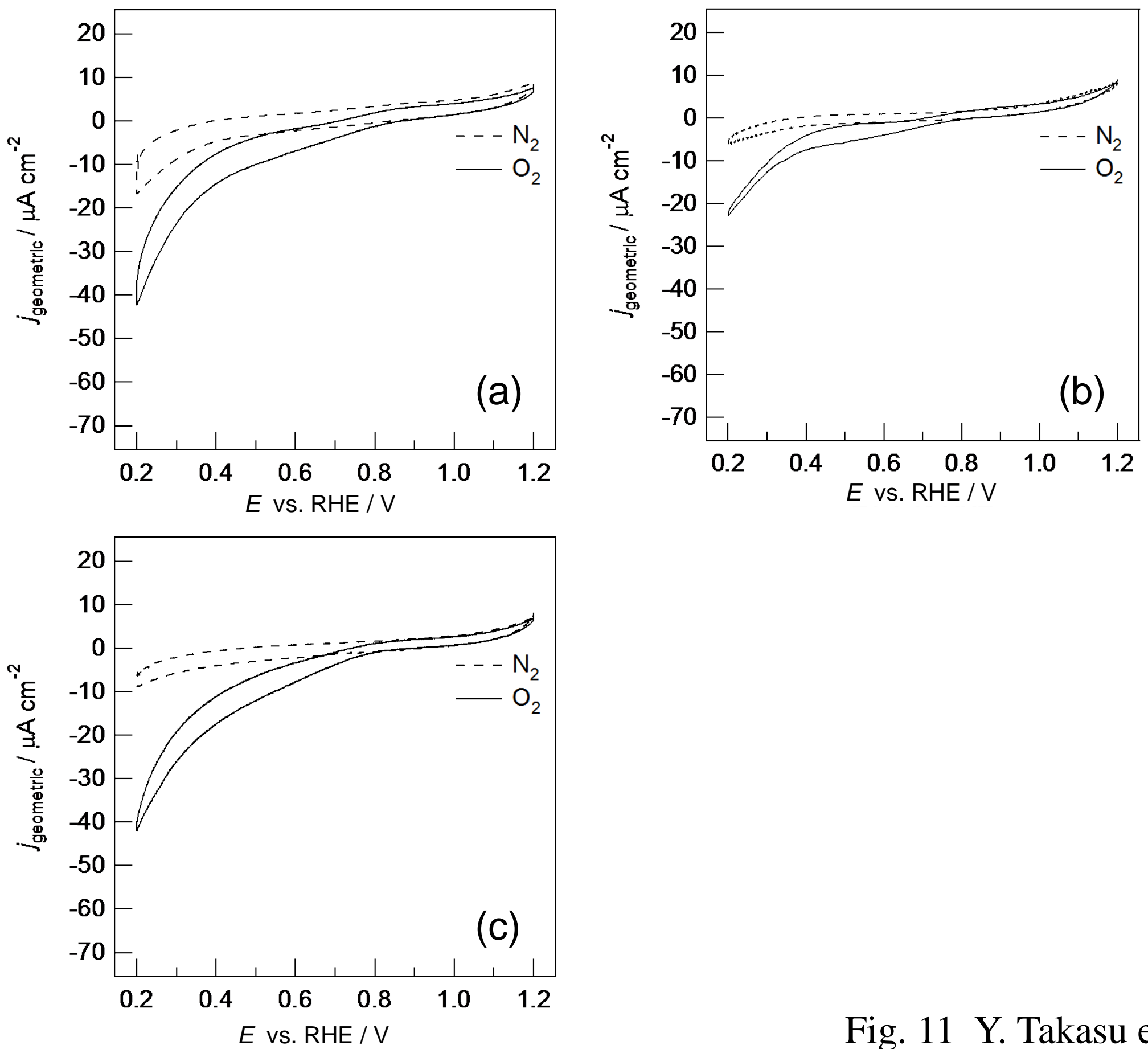

Fig. 11 Y. Takasu et al. 


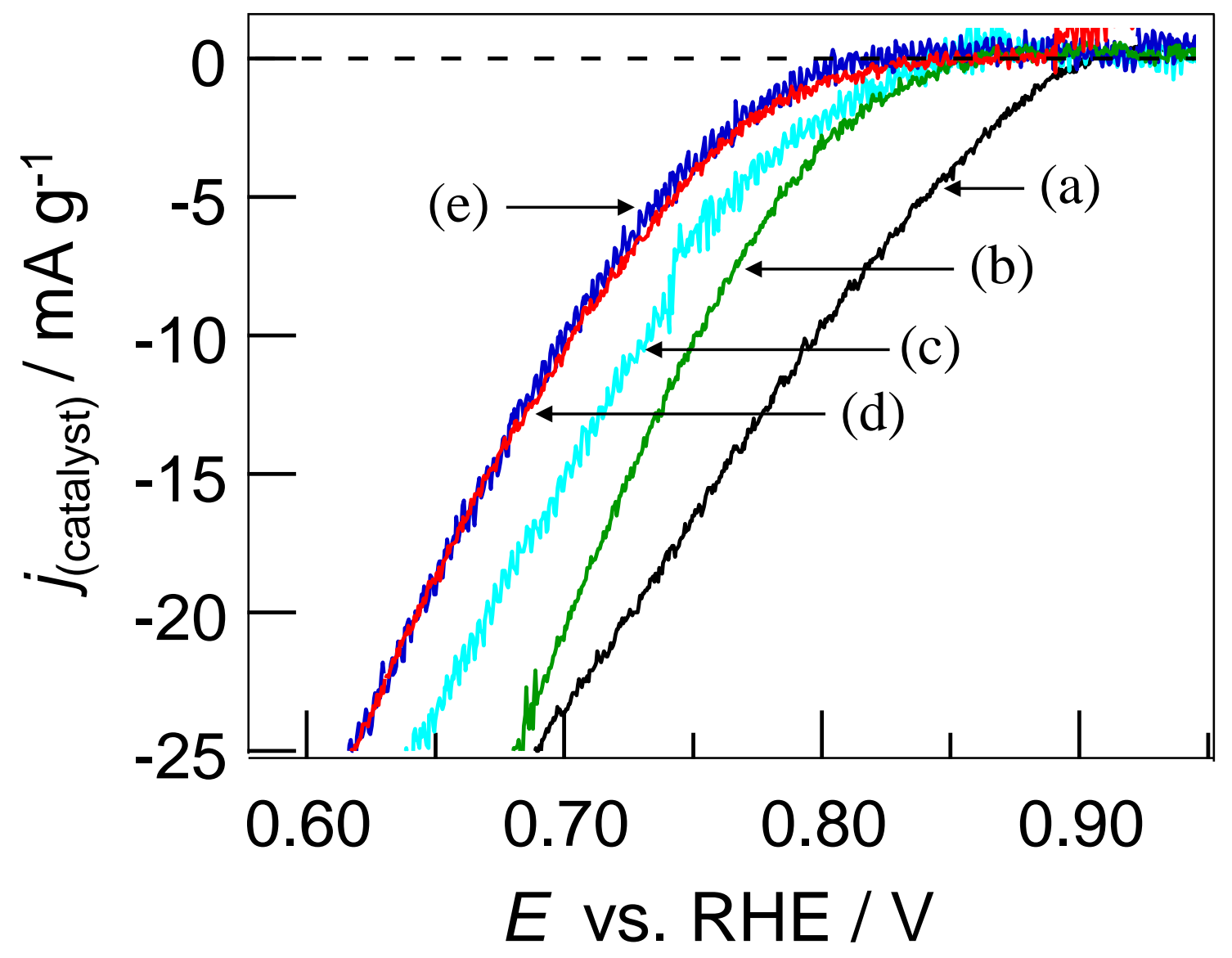

Fig. 12 Y. Takasu et al. 


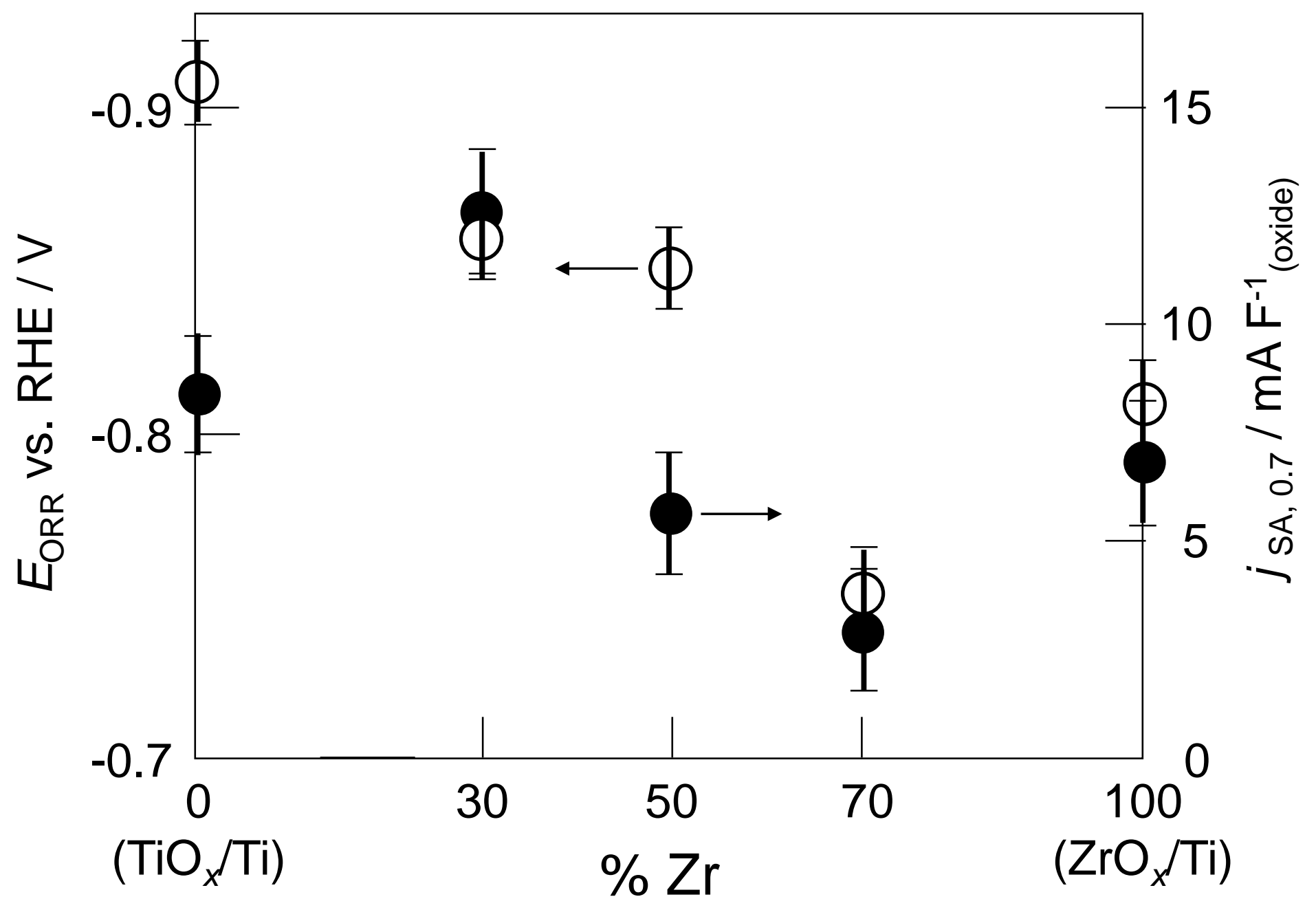

Fig. 13 Y. Takasu et al. 


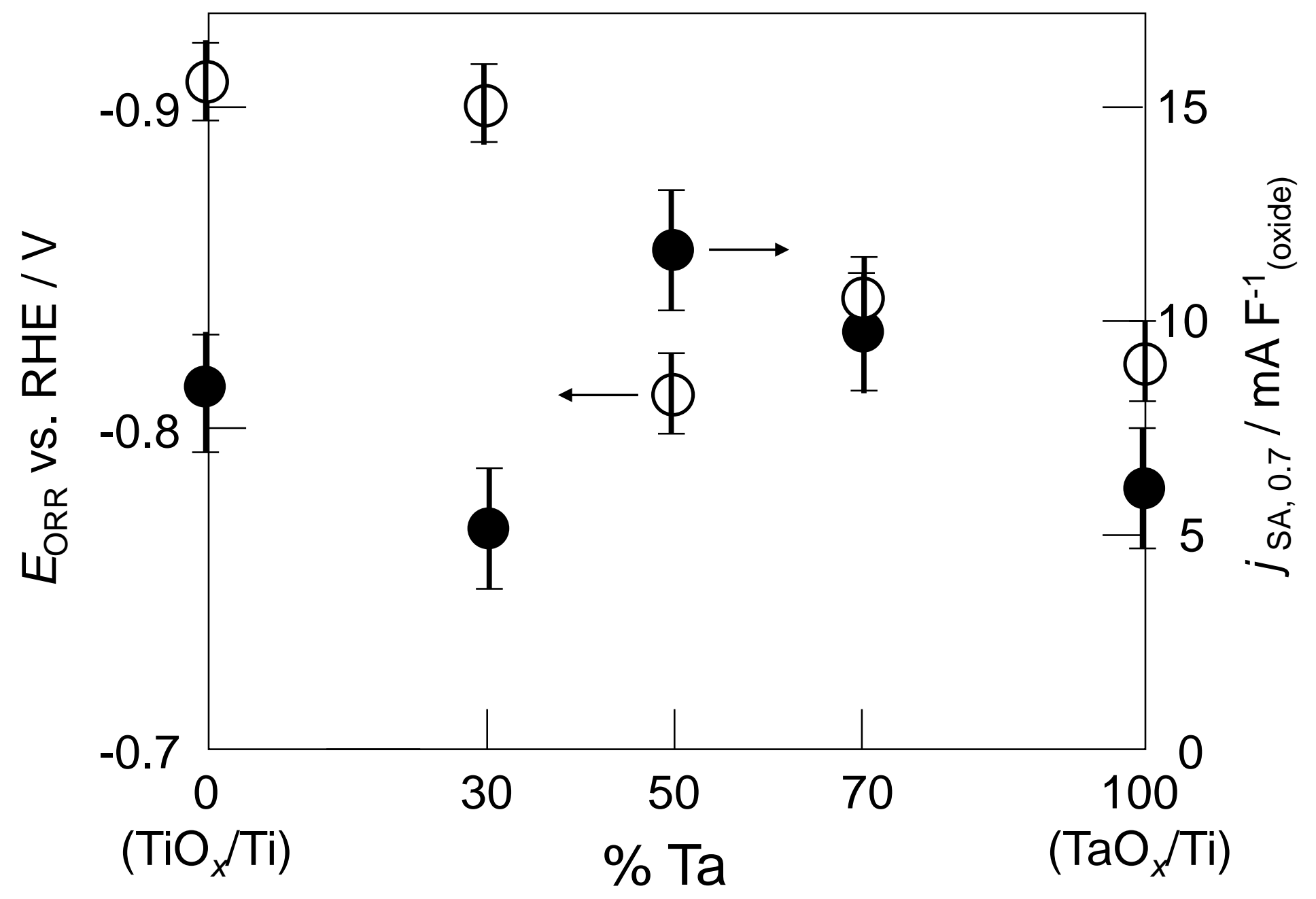

Fig. 14 Y. Takasu et al. 


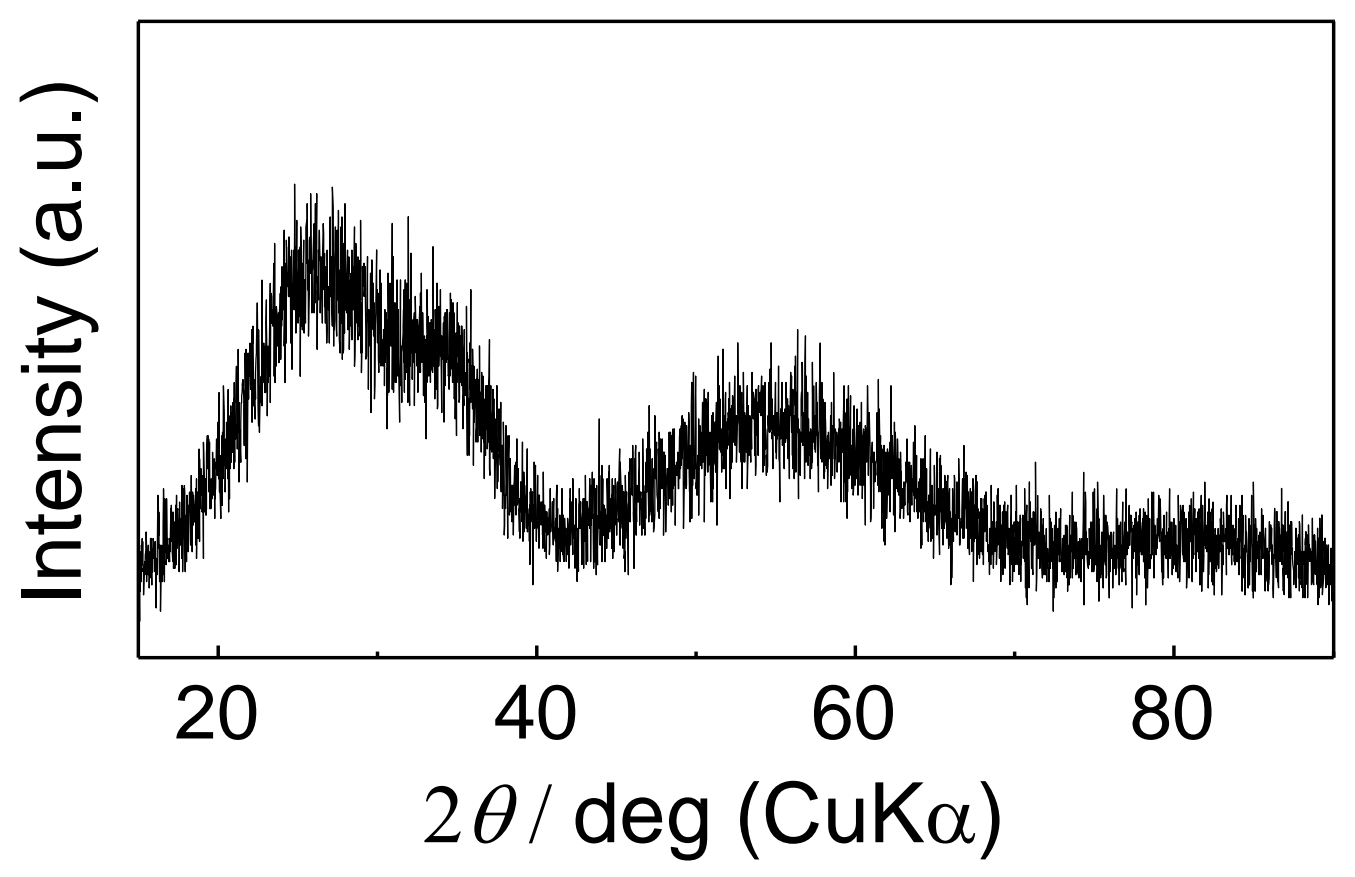

Fig. 15 Y. Takasu et al. 


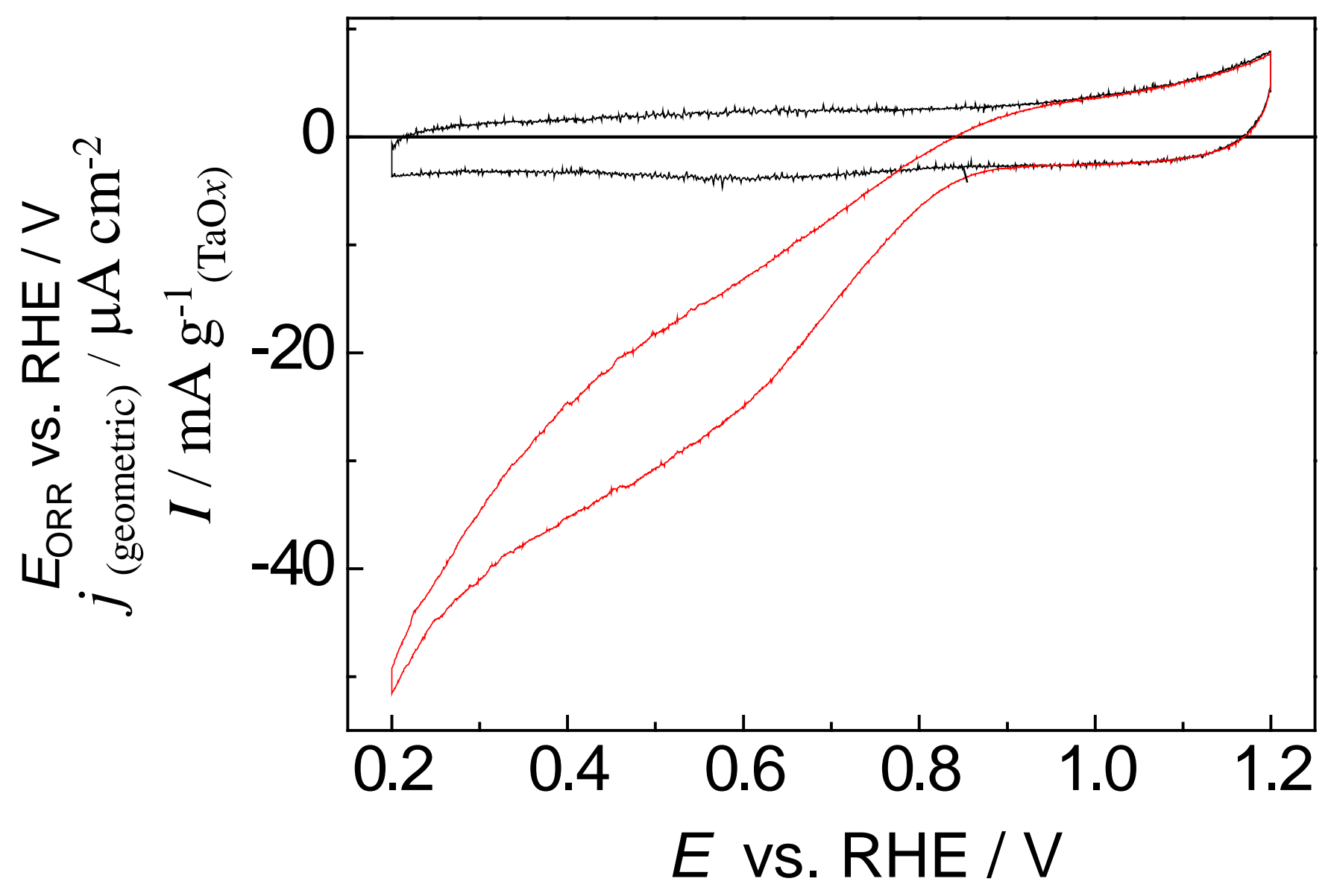

Fig. 16 Y. Takasu et al. 


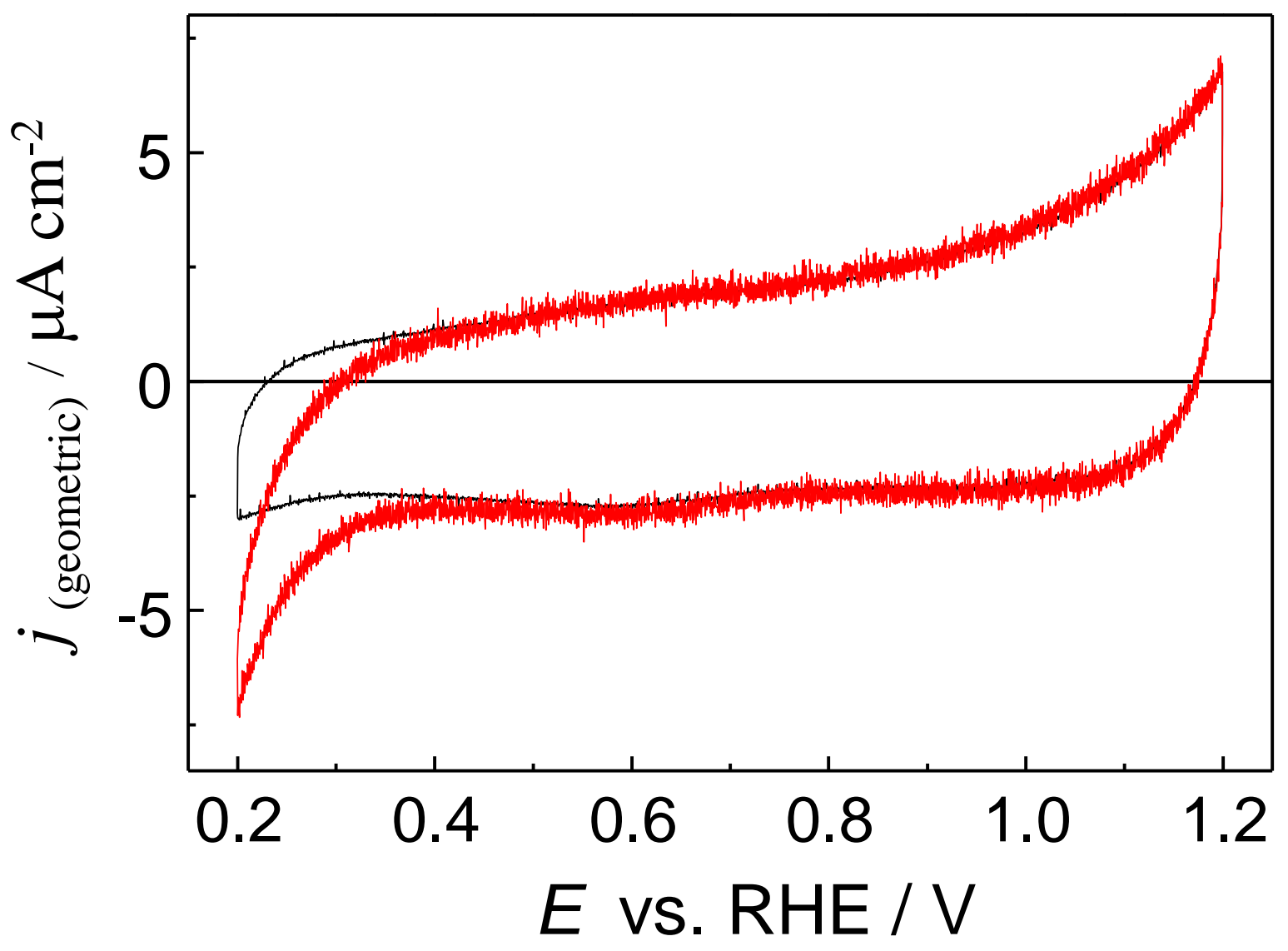

Fig. 17 Y. Takasu et al. 